\title{
Federated States of Micronesia: Selected Issues and Statistical Appendix
}

This Selected Issues paper and Statistical Appendix for the Federated States of Micronesia was prepared by a staff team of the International Monetary Fund as background documentation for the periodic consultation with the member country. It is based on the information available at the time it was completed on February 13, 2007. The views expressed in this document are those of the staff team and do not necessarily reflect the views of the government of the Federated States of Micronesia or the Executive Board of the IMF.

The policy of publication of staff reports and other documents by the IMF allows for the deletion of market-sensitive information.

To assist the IMF in evaluating the publication policy, reader comments are invited and may be sent by e-mail to publicationpolicy@imf.org.

Copies of this report are available to the public from

International Monetary Fund $\bullet$ Publication Services

700 19th Street, N.W. • Washington, D.C. 20431

Telephone: (202) 6237430 • Telefax: (202) 6237201

E-mail: publications@imf.org• Internet: http://www.imf.org

Price: $\$ 18.00$ a copy

\section{International Monetary Fund Washington, D.C.}





\section{INTERNATIONAL MONETARY FUND \\ FEDERATED STATES OF MICRONESIA}

\section{Selected Issues and Statistical Appendix}

Prepared by Christopher Faulkner-MacDonagh and Bing Xu (both APD)

Approved by the Asia and Pacific Department

February 13, 2007

Contents

Page

Selected Issues

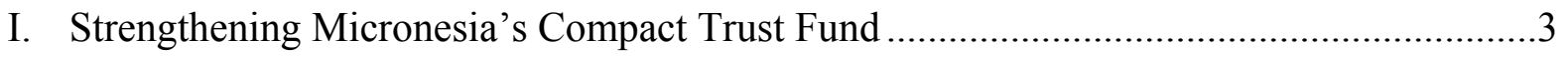

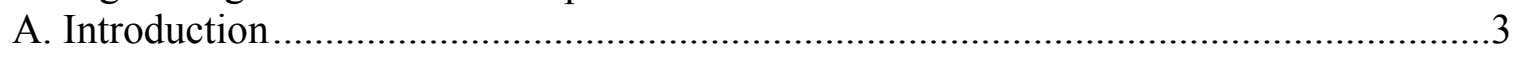

B. Operational Framework of the Trust Fund...................................................................

C. Initial Practices of the Trust Fund Management ........................................................6

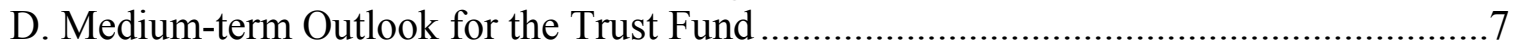

E. Improving the Operation and Oversight of the Fund ...................................................

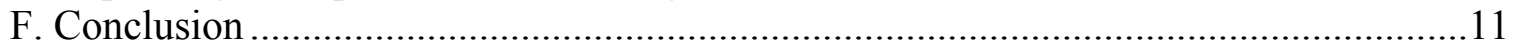

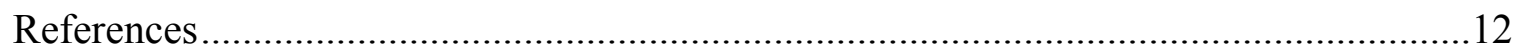

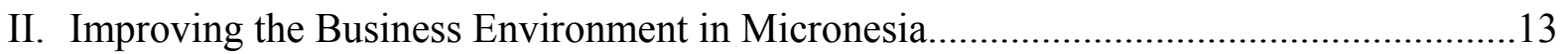

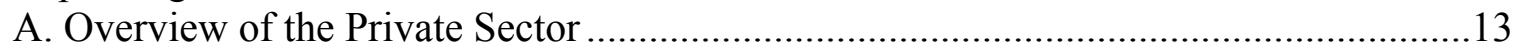

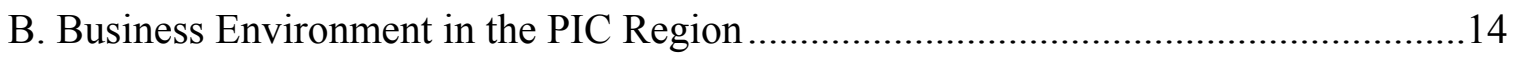

C. Difficult Business Conditions in Micronesia ……….................................................15

D. Recent Initiatives and Priorities for Further Reform ................................................17

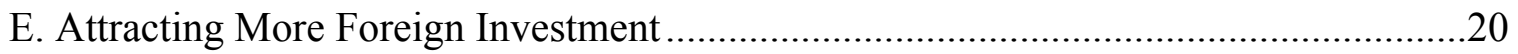

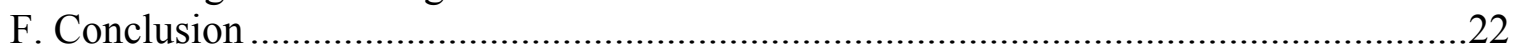

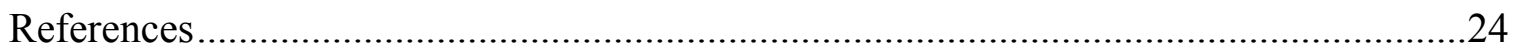

Boxes

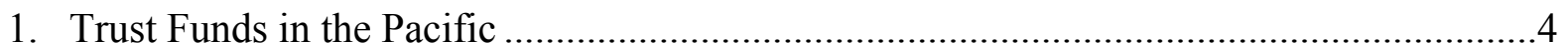

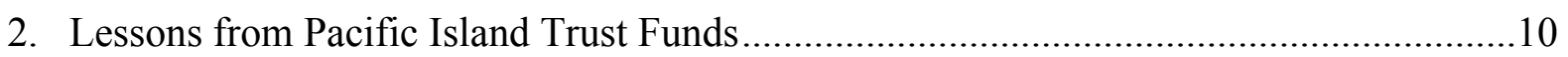

3. Policy Intentions to Promote Private Sector Development.................................................18

4. Recent Reforms in Closing a Business in Selected Countries ............................................19

5. Recent Reforms in Enforcing Contracts in Selected Countries .........................................20

Statistical Appendix

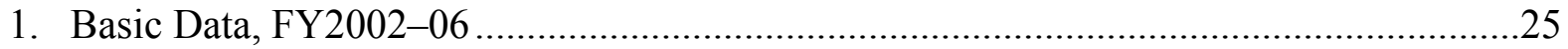

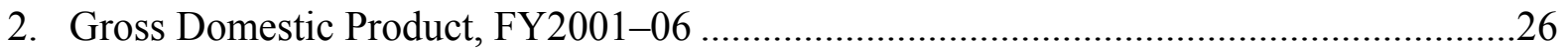




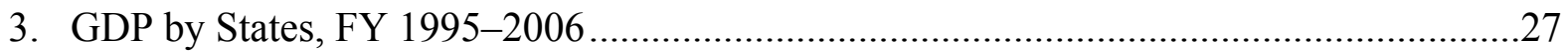

4. Public and Private Sector Employment and Wages, FY 2001-06 ..................................28

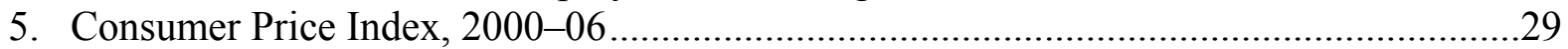

6. Pohnpei Consumer Price Index, 2000-06 ...................................................................

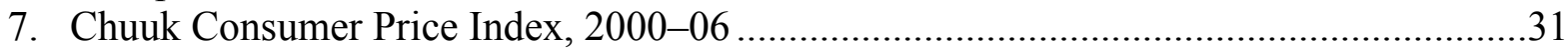

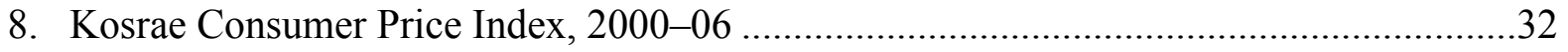

9. Yap Consumer Price Index, 2000-06 ...........................................................................3

10. Consolidated General Government Finances FY2001-06 .............................................34

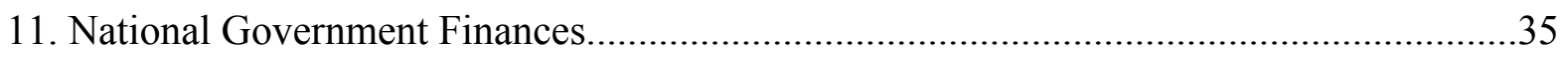

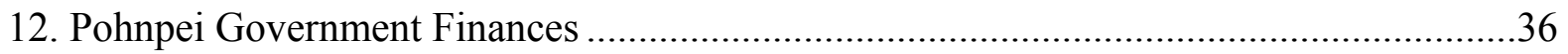

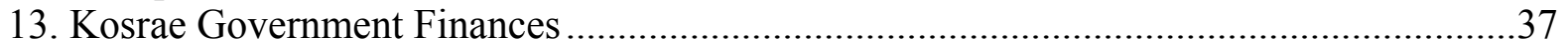

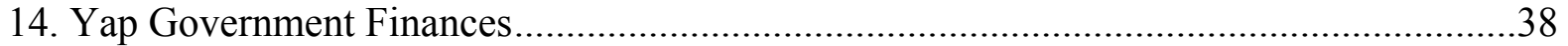

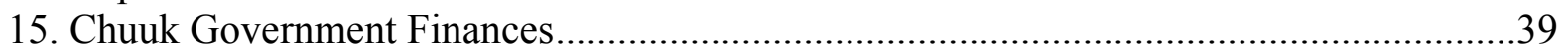

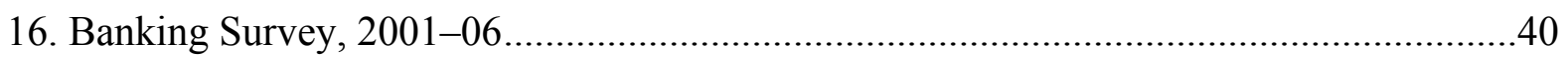

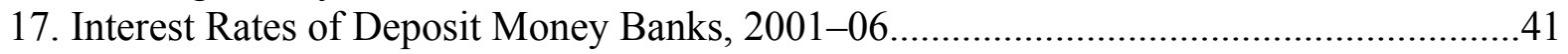

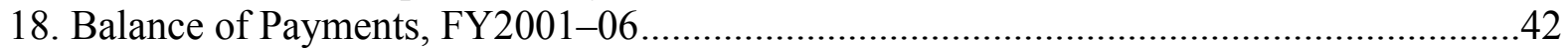

19. External Debt and Debt Service Obligations, FY2000-05 ..............................................43 


\section{Strengthening Micronesia's Compact Trust Fund ${ }^{1}$}

\section{A. Introduction}

1. The amended Compact of Free Association (FY2004-23) created a trust fund to help replace U.S. grants to the Federated States of Micronesia (FSM) after the Compact ends. During the Compact negotiations, there was a recognition this would be the last to provide substantial financial assistance. At the same time, both sides also realized that an abrupt end to aid would be disruptive. Thus, there was a need to create a mechanism to provide a more permanent source of assistance to help maintain living standards, which was also independent of a compact treaty with the United States.

2. The negotiators decided to establish a trust fund that would grow over the life of the Compact through a series of regular contributions. The agreement built in a gradual reduction of grant aid to the budget, which was meant to encourage greater financial selfreliance. At the same time, the saving from these reductions would be used to build up a Compact Trust Fund (CTF) that could be drawn upon after 2023. The design of the fund drew partially on the experience of other trust funds in the Pacific (Box 1).

3. However, the design and recent implementation of the CTF raise concerns that Micronesia will still face a difficult transition after U.S. aid ends in FY2023. The slow start and low initial returns of the fund suggest that the governance framework may need to be reexamined to ensure that the CTF achieves its overall objectives. This chapter examines the reasons for the poor initial performance and issues related to the governance framework of the fund. It also provides forecasts for the fund over the medium-term and concludes with some possible policy prescriptions to help bring fund's operation closer to the best practices used by other government-run trusts.

\section{B. Operational Framework of the Trust Fund}

4. The CTF was endowed in 2004 and will be funded over the next 20 years with a series of steadily rising payments. In 2004, the Micronesian government capitalized the fund with a $\$ 30$ million endowment. Since then, the United States has contributed around \$16 million. U.S. payments are scheduled to rise by around $\$ 800,000$ per year (partially

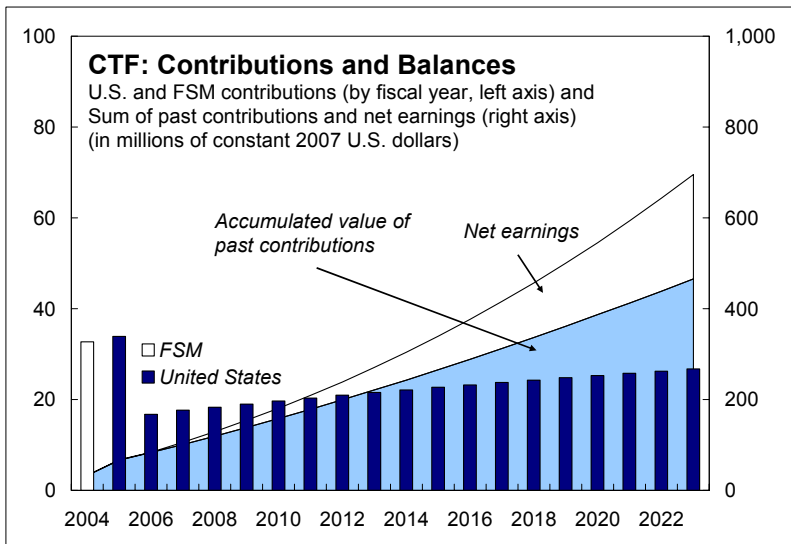

${ }^{1}$ Prepared by Christopher Faulkner-MacDonagh (ext. 35978). 


\section{Box 1: Trust Funds in the Pacific}

At least seven Pacific Island countries established trust funds to manage large, anticipated inflows, either from natural resources or with the support of international donors.

Kiribati Revenue Equalization Reserve Fund (1956). The fund was capitalized from phosphate mining revenue. It is entirely locally run, with the trustees consisting of the Minister of Finance (chair), the Secretary to the Cabinet, the Chief Accountant, and two others. In 1996, the fund adopted a target of maintaining a constant real per capita value. Prudent fiscal management by successive governments and sound investment policy enabled the trust's value to increase for many years in real terms, although it has come under pressure from high government draw-downs to finance budget deficits since 2003.

Tuvalu Trust Fund (1987). The fund was initially capitalized with \$A27 million, primarily by donors (United Kingdom, New Zealand, Australia Japan, and Korea), but also with a contribution from Tuvalu. The fund was created to provide budget support and to promote financial independence. The board of directors are from Tuvalu (chair), Australia, New Zealand and the United Kingdom. Sound investment decisions and limited withdrawals have helped lift the value of the fund considerably. To prevent large fluctuations in investment income from disrupting the budget, the fund established a dual account system, where one account served as a "buffer," that accumulated reserves during periods of high returns and could be drawn down during periods of low returns. (The CTF uses a similar system, drawing on the Tuvalu experience.)

Compact Trust Fund-Palau (1994). The United States provided the initial capitalization of $\$ 70$ million (1995-97), with an aim to replace the government's reliance on U.S. grants after the Compact expires in 2044. Palauans comprise the seven-member board. The government could withdraw limited amounts starting in 1999, but chose to reinvest most of the earnings, lifting the fund to $\$ 150$ million by 2004 . The long-run outlook is uncertain, because the fund was based on a highly optimistic assumption of annual returns of $12 \frac{1}{2}$ percent during the first 15 years.

Compact Trust Fund-Republic of Marshall Islands and Federated States of Micronesia (2004). The operation of these funds are nearly identical, although the U.S. contributions are higher to Micronesia's fund (reflecting the country's larger size and higher Compact grant funding).

Nauru Phosphate Royalties Trust (1968). The Trust was capitalized using dividends and taxes from phosphate mining and was intended to provide income after reserves ran out. High initial revenues swelled the balance to $\mathrm{A} \$ 1 \frac{1}{2}$ billion in 1990. As reserves ran out, mining contributions to both the budget and the trust fund fell, and the government borrowed heavily, using the fund as collateral. These draw-downs, along with poor investment returns and corruption, caused the fund to be virtually exhausted.

Tonga Trust Fund (1988). The fund was capitalized from the sale of passports to foreigners (primarily to residents of Hong Kong SAR) and the lease of Tongan satellite space. The Board of Trustees comprised of the Prime Minister (chair), Minister of Finance, plus one. The funds were invested in bank deposits until 1999, and the balance rose to \$26 million. In 1999, the King appointed a U.S. citizen as the investment manager, who lost the entire balance by 2002.

Marshall Islands Nuclear Claims Fund (1986). The United States provided $\$ 150$ million to compensate residents who suffered from U.S. nuclear testing between 1946-58. While the fund was intended to last in perpetuity, the fund fell by 15 percent in value during the 1987 stock market and never recovered, in part because of large payments to the victims of testing. The current fund balance is only around $\$ 5$ million. 
inflation-indexed) through 2023. ${ }^{2}$ The U.S. contribution schedule is, in effect, heavily back-loaded. As a result, by the end of the Compact, the principal is estimated to account for just over two-thirds of the overall balance of the fund.

5. The agreement governing the trust fund places oversight in the hands of a Joint Trust Fund Committee (JTFC). The committee is comprised of three members from the United States and two from Micronesia. ${ }^{3}$ The initial responsibilities included hiring service providers: (i) a trustee ${ }^{4}$ to collect funds, manage the disbursement, and act as the day-to-day overseer; (ii) investment managers to recommend a portfolio; and (iii) money managers to handle the funds. The JTFC was also to establish, and regularly revise, an investment policy. ${ }^{5}$

6. There are also specific financial controls, aimed at safeguarding the fund. Chief among these is a prohibition of borrowing against future trust fund income and a separation of U.S. and Micronesian contributions into different accounts. The agreement requires an annual report and audit within six months after the end of the fiscal year. These reports must clearly "segregate and identify gross income, management fees, and net income."6

7. Indeed, these financial controls even outlive the Compact and impose conditions on the use of funds during the draw-down phase. Starting in FY2024, and running until FY2043, the JTFC would oversee the allocation of income from the fund. Disbursements are to be targeted to the same areas (health, education, environment, infrastructure, capacity building, and private sector development) — and to use the same fiscal expenditure controlsas under the existing Compact. If Micronesia fails to meet the requirements specified in the agreement, the United States has the right to withdraw the present market value of all its contributions and net earnings.

8. The agreement preserves the nominal value of the CTF by limiting withdrawals. The agreement creates three accounts: (i) the " $\mathrm{A}$ " account that is the capital of the fund; (ii) the "B" account that holds all of the investment income from the " $\mathrm{A}$ " account starting in FY2023; and (iii) a "C" account that acts as a "buffer" (from FY2004-22, investment income above six percent is deposited into the "C" account). Starting in FY2024, the JTFC can draw down on the CTF, but only through the "B" account (and if any funds are available, from the "C" account).

\footnotetext{
${ }^{2}$ The Compact indexes payments using two-thirds of the annual increase in the U.S. GDP price deflator.

${ }^{3}$ Other members may be added, as long as the United States retains a majority vote.

${ }^{4}$ The trustee must also: (i) be a U.S.-based trust institution; (ii) have a net worth greater than $\$ 100$ million; (iii) have at least ten years managing trust assets; and (iv) have experience managing trusts of at least \$500 million. (FSM/US Trust Fund Agreement, 2002, Article 11, Section 3).

${ }^{5}$ FSM/US Trust Fund Agreement, 2002, Article 14 (Section 1).

${ }^{6}$ FSM/US Trust Fund Agreement, 2002, Article 17 (Section 3).
} 


\section{Initial Practices of the Trust Fund Management}

9. The JTFC experienced a slow start, resulting in low returns. The Micronesian and U.S. governments did not fully staff the JTFC until July 2005. The board members did not approve an investment advisor until September 2005-and a trustee until May 2006. As a result of the delay, the CTF was invested in bank deposits and money market funds, earning around 21/2 percent (Micronesia OPNA, 2006).

\section{The slow start resulted in missing important deadlines for producing financial}

statements. The first annual report was not produced until March 2006, more than one year late and was not audited. By October 2006, an auditor had not been selected. The annual report (JTFC, 2006) did not provide a full report on the accounts, including balances, gross returns, and management fees. Also, the JTFC has not conducted a long-term analysis of the fund's operation whether current policies would meet the goals spelt out in the agreement.

\section{Many of the difficulties in implementation appear to be the result of the JTFC} attempting to fulfill many roles. The Micronesian and U.S. governments decided to appoint the same people to the JTFC as to JEMCO — the joint committee responsible for overseeing and approving Compact grants. However, committee members have spent a significant amount of time to resolve problems that arose in implementing the new Compact. (GAO, $2006 \mathrm{~b}$, has a summary of the grant management issues experienced over the past three years).

12. This diffuse responsibility has meant that the committee has not met regularly to focus on issues surrounding the trust fund. Meetings are only required annually and have been tacked on at the end of the U.S.-Micronesia Compact meetings to consider grant requests by the national and state governments. This has not afforded the committee sufficient time to focus on the long-range, complex, and strategic issues involved in running a trust fund.

\section{The JTFC also does not appear to have the requisite experience to effectively}

manage a trust fund. Micronesian members are currently the head of the Office of Compact Management and the Secretary for Foreign Affairs. Although well-qualified in their fields of expertise, neither specialize in financial affairs, nor do they have staff whom could be drawn upon to analyze the performance of the fund, monitor the investment advisors, provide independent analysis of advisors' recommendations, and produce long-range forecasts.

\section{However, such experience is available in Micronesia, and some governmental} units have managed financial assets well. The Micronesian Department of Finance and Administration has managed the financial investments of the national government and states at a relatively low cost (around 80 basis points), yielding comparable returns as larger investors. The state of Yap has done a good job managing its state-owned trust fund (around $\$ 30$ million), which provides a significant share of the state government's revenues. The Micronesian Social Security Administration (SSA) invests workers' contributions in a broad mix of assets, guided by U.S.-based investment advisers. Their annual accounts are audited 
and made public on the web site. They provide a clear description of costs, gross and net returns, and assets, along with long-range actuarial forecasts (FSM SSA, 2006).

\section{Medium-term Outlook for the Trust Fund}

15. This section provides a medium-term analysis for the balance of the trust fund and its ability to meet the funding needs of the Micronesian government. This analysis is motivated by findings that CTF could fail to provide enough income in FY2024 to replace expiring Compact grants (GAO, 2003).

\section{The analysis considers outcomes of the fund under three scenarios regarding the investment strategy and management:}

- $\quad$ Conservative strategy. The gross nominal investment returns are assumed to be seven percent, with management and custodial fees of 100 basis points. This net return (six percent) matches the assumed rate of return when the U.S. Department of State designed the trust fund (GAO, 2006a). The designers of the fund assumed a return that was only marginally higher than the long-term forecasted returns on U.S. Treasury bonds, to reflect a conservative investment strategy.

- $\quad$ Authorities 2006 strategy. Partly because of the slow start to investing the CTF funds and need to raise returns, the authorities chose a more aggressive investment strategy. In August 2006, the trust fund was invested 100 percent in equities (57 percent in a fund tracking the Russell 3000 , and 43 percent in a fund tracking the MSCI EAFE index). ${ }^{7}$ Over time, bonds will be gradually added. This simulation assumes that the equity share is reduced by three percentage points annually $\left(1 \frac{1}{2}\right.$ percent for each equity fund), until equities account for only about one-third of holdings ( 24 percent in U.S. equities; 10 percent international). The reduction in the share of equity assets is used to purchase short (six month), medium, (five year) and long-term (ten year) U.S. Treasury bonds. The scenario assumes that the rebalancing process keeps the share of each maturity of bonds in its portfolio equal.

The investment returns from this strategy are calculated using historical yields on these funds. On average, net real investment returns are around $4 \frac{1}{4}$ percent (about 75 basis points higher than the real return in the Conservative investment strategy). This return is not constant, but simulated by randomly drawing yields from the historical experience of the joint, total returns of the five indices (U.S. Russell 3000, MSCI EAFE, and total returns of bond indices for the six-month, five-year, and tenyear Treasuries). Management fees are assumed to be 100 basis points.

\footnotetext{
${ }^{7}$ Many providers offer investments that follow these two indices. The Russell 3000 is an index fund of the shares of the 3,000 largest U.S. companies. The MSCI EAFE is Morgan Stanley Capital International's index, covering equity markets in 21 industrialized economies in Europe, Australasia, and the Far East.
} 
- $\quad$ Authorities 2006 strategy, plus another 100 basis points higher management fees. This scenario assumes the same investment strategy as is currently being followed. However, management and custodial fees are 200 basis points, claiming 2 percent of assets each year. Under this assumption, the total returns to the fund fall sharply, reflecting the large effect that fees have on the eventual outcome of the fund.

17. To maintain the focus on the effects of differing asset management strategies, the three scenarios use common economic assumptions. CPI inflation is $2 \frac{1}{2}$ percent annually, equal to long-term U.S. inflation estimates, since the U.S. dollar is the official currency. Medium-term real GDP growth is $3 / 4$ percent, assuming labor productivity grows at $1 / 2$ percent per year, and the labor force expands only $1 / 4$ percent per year (equal to long-run estimates of Micronesian population growth). This growth rate is based on unchanged economic policies. If structural reforms and fiscal adjustment are implemented, then GDP growth could reach $23 / 4$ percent annually. The U.S. GDP price deflator (used to calculate annual U.S. support) is taken from official U.S. sources. ${ }^{8}$ The scenarios, below, do not consider different economic assumptions, because such changes would alter the relative importance of the trust fund to the Micronesian economy and obscure the direct effects of investment strategies on the fund's value.

18. Under the Conservative investment strategy, the CTF will fall well short of what is needed to replace expiring Compact grants. Compact grants would be $19 \frac{1}{2}$ percent of GDP in FY2023, while the income from the fund would be only $12 \frac{1}{4}$ percent of GDP in the following year. Going forward, investment income would continue to be well below the FY2023 Compact grant levels. ${ }^{9}$ Furthermore, the agreement only attempts to preserve the fund's nominal value by preventing the government from making withdrawals from the "A" Account. Thus, the Micronesian government could withdraw all investment income each year, leaving no reserves to ensure that the fund grows to keep pace with inflation. Over time, the funds' real per capita value would also fall, implying

\footnotetext{
${ }^{8}$ For 2007-11, U.S. Office of Management and Budget estimates GDP price inflation at 21/4 percent. For 2012-15, U.S. Congressional Budget Office estimates GDP price inflation at 13/4 percent per year, and this simulation assumes inflation is constant and equal to the rate in 2015.

${ }^{9}$ Investment returns during the draw-down phase would likely be well-below those during the accumulation phase, because the government would need to shift its portfolio toward bonds and other less risky-and lower yielding — securities to preserve the fund's principal.
} 
dwindling resources for the government. (The present value of the fund required to maintain constant spending is near $\$ 1$ billion.)

19. A loss of income of this magnitude would imply a sustained drag on growth. The forecast would foresee a loss of revenue of around 7 percent of GDP in FY2024. This would force immediate and painful cuts in government spending. Their effect would be magnified, because government income would be permanently lower - and falling at a rate equal to inflation plus population growth.

20. The Authorities 2006 investment strategy would have only a marginal impact on the fund's balance in FY2023. Under this scenario, the trust fund is estimated to be only $43 / 4$ percent larger than if the Conservative investment strategy were followed. This small improvement reflects, in part, the decision to gradually shift to a more conservative asset allocation. However, even more risky strategies would not improve the outcome significantly. If the portfolio were not diversified (keeping 100 percent in equities, with a 53/47 split between U.S and international stocks), the balance of the fund would be 12 percent higher than the Authorities 2006 investment strategy-again, well below what is required. These riskier strategies have a small impact because contributions are back-loaded; in the final four years, they account for nearly one-quarter of the FY2023 principal.

21. Analysis also suggests that a significant risk to the fund are management fees. ${ }^{10}$ With a 100 basis points increase in management fees, the trust fund balance would be nearly 10 percent ( $\$ 70$ million 2007 U.S. dollars) lower. This suggests that every effort should be made to keep costs under control.

\section{E. Improving the Operation and Oversight of the Fund}

22. Given the importance of the CTF to the future of Micronesia, it is essential that the board members overseeing the fund adopt best practices (Box 2). Regardless of the rate of growth of the Micronesian economy, it is very likely that the trust fund will provide a large share of the government's revenue. It is essential that the investment managers act promptly to take the greatest advantage of the long time horizon. At the same time, the JTFC must exercise strong oversight in monitoring the service profits, to help hold down costs from fees - one of the biggest risks to the fund.

\section{The CTF agreement has strong controls in place, particularly over the} monitoring and eventual disbursement of funds. Micronesia must implement the fiscal controls in order to receive disbursements from the CTF. Similarly, the JTFC must produce audited annual reports.

\footnotetext{
${ }^{10}$ Fees at U.S. university endowments average 40 basis points (NACUBO, 2003) for investment and custodial services, although this includes internally managed endowments. Charges for the externally-managed trusts for the University of California are higher, at 70 basis points (Office of the Treasurer of the Regents, 2003). The investment and custodial fees for the Micronesian Social Security System is 90 basis points (FSM SSA, 2006).
} 


\section{Box 2. Lessons from Pacific Island Trust Funds}

A review of Pacific island trust funds distills a set of concrete recommendations and best practices reflecting their experiences (both success and failures).

\section{Good governance:}

- $\quad$ Independent operation. The trust fund committee must be able to withstand political pressure. In Kiribati, the Minister of Finance is the chair (in Palau, the President). In Tuvalu, while there is significant donor involvement, there is also considerable local involvement in decision-making.

- Local ownership and understanding. The fund should have locally-determined goals. Ideally, these are contained in legislation, which affords public debate. The public should also be updated regularly if the fund is on track to achieve its goals.

- $\quad$ Open and transparent operation. The trust fund should be subject to annual audits. Annual reports are essential, but the public should also have quarterly reports on the balances, income, and costs of the fund, along with a simple update of long-range forecasts from the last annual report.

\section{Strong fiduciary practices:}

- $\quad$ Robust fiscal controls. A fund should specify, at the outset, how its income will be spent, and an effective fiscal management system should be in place before withdrawals occur.

- Clear investment goals. The investment managers must be benchmarked against clear financial targets. To that end, an ideal policy statement clarifies the overall objectives, asset allocations, risk tolerance (including views on diversification, rebalancing, and liquidity), and the measurement of performance.

- $\quad$ Close scrutiny of costs and service providers. The committee should use only reputable providers, but also look for ways to minimize costs. This requires knowing what competitors charge; re-bidding contracts regularly; and enforcing contractual terms (firing poorly performing providers, if needed).

- $\quad$ Maintenance of the real per capita value of the fund. Irrespective of any other goals, a trust fund must be able to preserve its real per capita value. If not, then it will eventually be depleted.

24. Here the priority should be to upgrade the governance structure. The trust fund and JTFC should take on a higher profile in Micronesia. This would include greater public discussion regarding the role of the trust fund and a clearer description of the challenges that Micronesia faces in 2023. These goals could be achieved by:

- $\quad$ Delinking the JTFC from the committee implementing the Compact. Trust fund operations are different from the rest of the Compact, and effective oversight requires that the committee be staffed with professionals with financial expertise. This would also provide greater scope for local involvement.

- $\quad$ Elevating the status of the JTFC through including the Secretary of Finance and Administration. This step would help highlight the fund's importance for Micronesia's future. Since the committee does not have a budget, the Secretary could also draw upon his or her staff to oversee the fund more effectively. 
- $\quad$ Aiming for greater openness regarding the operation and decisions of the JTFC. The annual report should be audited and published. Thereafter, the committee should aim to provide a quarterly report on the fund's status. Future annual reports should analyze if there is a need for corrective action, by including a medium-term vulnerability analyses. Preferably, minutes should be published, and the members should meet with the public (including legislators) to explain the annual report.

25. Additional improvements could be made to the JTFC's fiduciary practices. To strengthen accountability, the committee should explain its choice of advisors and their fees. Micronesia has yet to publish investment strategy or look at its investments, costs, and operations strategically. The committee's operation would be improved by:

- $\quad$ Adopting a simple and clear investment objective. The fund's purpose is difficult to implement in practice. ${ }^{11}$ Instead, the committee could consider a simple mandate for the investment managers similar to other funds, such as to maximize returns while preserving the fund's capita.

- $\quad$ Examining the impact of a target of holding the fund's balance at a real per capita level. While a real per capita target is not part of the agreement, the Micronesian government would come under fiscal pressure if it merely maintains a constant nominal value. An examination and publication of this information would help build support for early action to address the projected shortfalls.

\section{F. Conclusion}

\section{Given the CTF's importance, reforms are needed to raise the profile of its} management committee and adopt a more strategic approach to investment. When Micronesia begins drawing down on the fund, it will represent a significant - if not the primary - source of funding for the government. However, the initial experience has been mixed, owing to a diffuse responsibility placed on the JTFC. By taking early measures to enhance the existing governance and fiduciary responsibilities, Micronesia can build public awareness of the importance of the fund and the challenges it faces. Providing more information is vitally important, but the current lack of awareness means that the committee's reports are not likely to garner much attention. To that end, the committee members have an important role in educating the senior government officials, legislators, and the public at large about the Trust Fund. Such efforts are time consuming, but if reforms are enacted now, the Micronesian government will gain greater experience in managing and investing the fund, which should serve it well once the Compact expires.

\footnotetext{
${ }^{11}$ According to the Agreement, "the purpose of the Fund is to contribute to the economic advancement and long-term budgetary self-reliance of the Federated States of Micronesia by providing an annual source of revenue, after FY2023." (FSM/US Trust Fund Agreement, 2002, Article 2).
} 


\section{REFERENCES}

FSM ONPA, 2006, "Inspection of the Compact Trust Fund," Office of the National Public Auditor (ONPA) 2006-03, July.

FSM SSA, 2006, FSMSSA 2005 Annual Report (Pohnpei: FSM Social Security Administration) December.

FSM/US Trust Fund Agreement, 2002, available at: http://www.fm/jen/docs/tfa.pdf.

GAO, 2003, Compacts of Free Association: An Assessment of the Amended Compacts and Related Agreements, GAO-03-890T (Washington: Government Accountability Office) June.

GAO, 2006a, Compacts of Free Association: Development Prospects Remain Limited for Micronesia and Marshall Islands, GAO-06-590 (Washington: Government Accountability Office) June.

GAO, 2006b, Compacts of Free Association: Micronesia and the Marshall Islands Face Challenges in Planning for Sustainability, Measuring Progress, and Ensuring Accountability, GAO-07-163 (Washington: Government Accountability Office) December.

Graham, Benjamin, 2005, Trust Funds in the Pacific: Their Role and Future. Pacific Studies Series (Manila: Asian Development Bank).

JTFC, 2006, Annual Report: Trust Fund for the People of the Federated States of Micronesia (unpublished; Federated States of Micronesia: Joint Trust Fund Committee) March.

NACUBO, 2003, NACUBO Endowment Study, National Association of College and University Business Officers (Washington: NACUBO).

Office of the Treasurer of the Regents, 2003, University of California Annual Endowment Report for the Fiscal Year ending June 30 (Oakland: University of California Regents). 


\section{IMPROVING THE BUSINESS ENVIRONMENT IN MICRONESIA ${ }^{12}$}

\section{The private sector in the Federated States of Micronesia (FSM) faces significant challenges from its limited resources and geographical remoteness. Situated in the} western Pacific, Micronesia consists of 607 islands spread across 1,800 miles. The small size of its economy, poor infrastructure, and high costs of energy and transportation are large impediments to business activity and investment, including from overseas. Compared to its neighbors, Micronesia is located farther away from the large eastern Asian countries, such as China and Japan, and lacks direct international flights to these markets. It relies almost entirely on oil imports for its energy needs and other than fish, exports very little.

\section{The difficult business environment in terms of regulations and administration} has also held back the growth of private sector. According to the World Bank's Doing Business in 2007: How to Reform report, ${ }^{13}$ Micronesia ranks $106^{\text {th }}$ in the world and last among Pacific island countries (PICs) in the ease in doing business. Partly as a result, private sector growth has languished. Using the World Bank data, this chapter examines the business environment in Micronesia and identifies possible areas for improvement. ${ }^{14}$ Improving the business climate is important as the public sector is expected to shrink with the expiry of the Compact, leaving the private sector as the key driver for growth and sustaining living standards.

\section{A. Overview of the Private Sector}

29. The role of the private sector has been limited to serving mainly the needs of the large public sector.

External grants have contributed to a large public sector which at 40 percent of GDP dominate the economy. The private sector is geared mainly to meeting the demands

\begin{tabular}{|lrr|}
\hline \multicolumn{3}{|c|}{ GDP and Employment by Sectors, 2001-05 } \\
\hline & $\begin{array}{c}\text { Average } \\
\text { Annual } \\
\text { Growth }\end{array}$ & $\begin{array}{c}\text { Percent } \\
\text { in Total }\end{array}$ \\
\hline GDP & 0.9 & 28.9 \\
Private sector & 2.2 & 40.4 \\
Public sector & & \\
Employment & -10.6 & 10.0 \\
Private non-service sector 1/ & 0.9 & 32.0 \\
Private service sector 2/ & 1.0 & 54.2 \\
Public sector 3/ & & \\
\hline Source: Micronesian authorities. & & \\
1/ Includes agriculture, tishing, mining, manutacturing, and construction. \\
2/ Includes wholesale, retail, transport, storage and real estate services. \\
3/ Includes government, health service, education and public financial sector. \\
\hline
\end{tabular}

${ }^{12}$ Prepared by Bing Xu (ext. 39521).

13 The Doing Business in 2007: How to Reform report is an annual exercise using quantitative indicators to measure the efficiency and effectiveness in 10 areas of business regulation across 175 economies in the world. More information can be found on the World Bank's web site at http://www.doingbusiness.org.

${ }^{14}$ As the World Bank notes, when interpreting the ranking results, the survey methodology suffers from certain limitations, such as its reliance on expert judgments, focus on limited liability companies, and the quality of available data. Nonetheless, they do offer a useful standardized basis for comparing and highlighting important differences in business conditions across countries. 
of the government which employs nearly 55 percent of the labor force. The main sectors within the private economy include agriculture, fishing, services (wholesale and retail), transportation, and construction. Tourism, commercial fishing, and other export-related activity remain largely underdeveloped.

30. Since 2001, private sector growth has stagnated. During 2001-05, private sector GDP grew by 0.9 percent on average, compared with 2.2 percent for the public sector. As a result, the private sector's share in GDP fell to 29 percent in 2005 , compared to 40 percent for the public sector. During this period, employment in manufacturing, construction, and tourism fell sharply, while in services, mainly retail, it expanded. Across the states, Yap experienced the fastest growth in private sector employment and output. The size and composition of the private sector also varies across the four

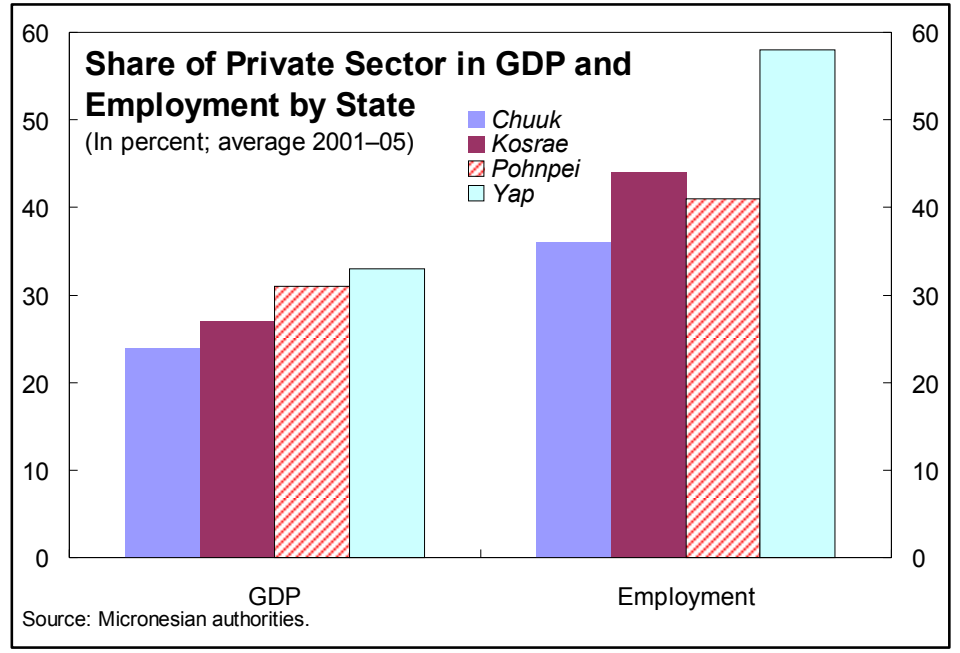
states. Yap has the largest the private sector, in terms of the share in total output and employment, while Chuuk the smallest.

\section{B. Business Environment in the PIC Region}

31. The results of the World Bank's Doing Business in 2007: How to Reform survey of the business and regulatory environment revealed some common features across the PICs. In 2006, the overall ranking of PICs ranged from Fiji in $31^{\text {st }}$ place to Micronesia at $106^{\text {th }}$. Across the ten business areas covered, the region as a whole scored fairly well in five areas - employing workers, dealing with license, paying taxes, business entry and trading across borders. In these areas, the PICs on average ranked above 50. However, they appeared less efficient in the remaining 5 areas, namely getting credit, enforcing contracts, closing a business, protecting investors, and registering property, where they ranked on average around 100 . These low average rankings

\begin{tabular}{|lc|}
\hline $\begin{array}{c}\text { Doing Business Economy Rankings } \\
\text { for the PICs }\end{array}$ \\
\multicolumn{1}{|c|}{ (From 1-175 with 1st place being the best) } \\
\hline Fiji & 31 \\
Samoa & 41 \\
Tonga & 51 \\
Papua New Guinea & 57 \\
Vanuatu & 58 \\
Kiribati & 60 \\
Palau & 62 \\
Solomon Islands & 69 \\
Marshall Islands & 87 \\
Micronesia & 106 \\
\hline \multicolumn{2}{|c|}{ Source: Doing Business in 2007: How to Reform } \\
(World Bank and IFC). \\
\hline
\end{tabular}
suggest some common weaknesses shared by this region. For example, rigid land tenure systems have been a long-standing feature of many PICs, while the poor access to financing (except for Fiji) may reflect the underdeveloped state of their financial systems. 
32. Notwithstanding the similar economic conditions, top performers in the region led the bottom performers by a large margin. The two top performers among the PICs were Fiji and Samoa ranking $31^{\text {st }}$ and $41^{\text {st }}$ in the world respectively. In contrast, the two economies at the bottom, the Marshall Islands and Micronesia, ranked $87^{\text {th }}$ and $106^{\text {th }}$. A closer examination shows that Micronesia sharpened the contrast between the region and the rest of the world. For example, Micronesia ranked higher the PIC's average in the five areas where the region was relatively more efficient, but ranked lower, by a large margin, in the areas where the region as a whole was weak. This also suggests that Micronesia has considerable room for improving its business environment in those areas where it lags behind its regional peers.

\section{There is evidence within the region suggesting a link between the business} climate and private sector growth. A simple plot of average growth rates during 2000-06 and the World Bank's Doing Business in 2007: How to Reform rankings show that PICs with lower costs of doing business featured faster average growth rates. With Micronesia ranking near the bottom among PICs in both the business environment and growth performance, improving the regulatory regime could yield significant economic benefits.

\section{Difficult Business Conditions in Micronesia}

34. Overall, Micronesia ranked $106^{\text {th }}$ among the 175 participating countries and at the bottom among PICs in the ease of doing business. While Micronesia ranked high (in the $1^{\text {st }}$ quartile) in the areas of employing workers, dealing with licenses, paying taxes, starting a business and trading across borders, it fared poorly in the areas of registering property, getting credit, protecting investors, enforcing contracts and closing a business. In 
these 5 areas, Micronesia ranked below 100 and in 4 of them, near the very bottom, which helped to drag down its overall ranking.

35. Micronesia's weakest area was in registering property. In this category, the survey looked at the costs involved for a medium-sized business to register a fixed area of property (557.4 square meters) in a semi-urban location. Since this is not possible in Micronesia due to the restrictions on land transactions, it ranked near the bottom of the world in this category $\left(172^{\text {nd }}\right)$, in stark

\begin{tabular}{|llcc|}
\hline \multicolumn{4}{|c|}{ Registering Property } \\
\hline & Micronesia & Palau 1/ & $\begin{array}{c}\text { PICs } \\
\text { Average }\end{array}$ \\
\hline Procedures (number) & No practice & 5 & 4.8 \\
Time (days) & No practice & 14 & 173 \\
Cost (percent of property value) & No practice & 0.4 & 5.2 \\
\hline \multicolumn{3}{|c|}{ Source: Doing Business in 2007: How to Reform } & (World Bank and IFC). \\
1/ Top performer among the PICs. & & \\
\hline
\end{tabular}
contrast to the average for the PICs and Palau, which was the top performer in this category. While land tenure represents a shared weakness with most other PICs, Palau was able to register such property in a relatively short period of time and at minimal cost, giving it a ranking of $13^{\text {th }}$ in this category.

\section{The process for enforcing contracts is also much less efficient compared to the}

PICs average. Micronesia ranked $139^{\text {th }}$ in enforcing contracts with the time and cost of enforcement significantly higher than the region. In particular, the period of judgment (365 days) and enforcement (400 days) were extremely long. Samoa, on the other hand, topped the PICs in this area (ranked $54^{\text {th }}$ )

\begin{tabular}{|c|c|c|c|}
\hline \multicolumn{4}{|c|}{ Enforcing Contracts } \\
\hline & Micronesia & Samoa 1/ & $\begin{array}{c}\text { PICs } \\
\text { Average }\end{array}$ \\
\hline Procedures (number) & 25 & 30 & 29 \\
\hline Time (days) & 775 & 455 & 518 \\
\hline Cost (percent of debt) & 77 & 15 & 58 \\
\hline Rank & 139 & 54 & 107 \\
\hline
\end{tabular}
with significantly shorter time and lower costs.

\section{Similarly, Micronesia took much longer and recovered much less in closing a}

business. It takes as long as 51/4 years, nearly twice the average for the region, to go through bankruptcy proceedings for a failed medium-sized business. At the end, the recovery rate is estimated to be only 3 cents on the dollar, compared to 21 cents for the region, giving Micronesia a ranking of $148^{\text {th }}$. Among the PICs, Vanuatu ranks the highest at $45^{\text {th }}$

\begin{tabular}{|c|c|c|c|}
\hline \multicolumn{4}{|c|}{ Closing a Business } \\
\hline & Micronesia & Vanuatu 1/ & PICs \\
\hline Time (years) & 5.3 & 2.6 & 2.4 \\
\hline Cost (percent of estate) & 38 & 38 & 33 \\
\hline \multicolumn{4}{|l|}{ Recovery rate } \\
\hline (cents on the dollar) & 3.1 & 40 & 20.8 \\
\hline
\end{tabular}
where closing a business takes half the time and recovers 13 times more than in Micronesia. 
38. Like other PICs, the private sector in Micronesia suffers from poor access to credit. Except for Fiji which ranked at $21^{\text {st }}$, other PICs ranked low between $100^{\text {th }}$ and $140^{\text {th }}$ in terms of access to credit. Fiji's strong performance appears be due to its legal framework and private credit registry system. ${ }^{15}$ In Micronesia and other PICs, the

\begin{tabular}{|c|c|c|c|}
\hline \multicolumn{4}{|c|}{ Getting Credit } \\
\hline & Micronesia & Fiji 1/ & PICs \\
\hline Legal Rights Index & 6 & 7 & 5.6 \\
\hline Credit Information Index & 0 & 4 & 0.4 \\
\hline $\begin{array}{l}\text { Public registry coverage } \\
\text { (percent adults) }\end{array}$ & 0 & 0 & 0 \\
\hline $\begin{array}{l}\text { Private bureau coverage } \\
\text { (percent adults) }\end{array}$ & 0 & 33.4 & 3.3 \\
\hline $\begin{array}{l}\text { Source: Doing Busin } \\
1 / \text { Top performer am }\end{array}$ & ow to & orlc & FC). \\
\hline
\end{tabular}
lack of credit information has hindered access to financing, particularly for unsecured loans, and may reflect the early development stage of their financial systems.

\section{Recent Initiatives and Priorities for Further Reform}

39. Although some recent initiatives will likely help the private sector, much more needs to be done to improve the business environment, particularly in the areas highlighted by the Doing Business in 2007: How to Reform report. The introduction of a new bankruptcy and secured transaction law are positive steps and will promote effective restructuring and new lending. Effective implementation and enforcement will be key for stimulating private business and building support for further reforms. At the same time, more work is needed to strengthen those weak areas highlighted by the Doing Business in 2007: How to Reform report. To summarize, the main priorities should be to: reduce the time and cost in closing a business, improve access to credit, strengthen the enforcement of contracts, and expand property registration. The fact that Micronesia significantly lags behind the rest of the region in these areas suggests that progress can be made with positive results.

\section{For starting a business, states have taken steps to lower the regulatory} requirements. In 2006, states eliminated the minimum capital requirement for starting a business (previously equivalent to $1 / 2$ of per capita income) which resulted in an significant improvement in their Doing Business in 2007: How to Reform ranking from $82^{\text {nd }}$ to $39^{\text {th }}$. In October 2006, the Pohnpei Registrar of Corporation announced plans to drop an article in the Corporation Law that linked the license fee to the number of shares in a business startup. This is estimated to reduce the cost of starting a business further from 136 percent of per capita income to 9 percent and would remove an important hurdle to starting a new business in Pohnpei.

\footnotetext{
${ }^{15}$ In the area of getting credit, two indices measuring legal protection of creditors and depth of credit information are used, with a score ranging from 0-10 assigned to each of the two indices. The coverage of public and private credit registries is also measured.
} 


\section{Box 3. Policy Intentions to Promote Private Sector Development}

In the Third Economic Summit held in March 2004, Micronesia formulated a Strategic Development Plan outlining their reform agenda for the private sector. As part of the amended Compact, the plan envisaged a strong commitment to fiscal discipline and regulatory reform as a way of improving the business climate. The goal was to raise private investment from 7 percent of GDP in 2003 to 17 percent of GDP by 2023. Specifically, the strategy called for:

- Limits on the size of government;

- Making tax regime consistent with outward-oriented economic strategy;

- Encouraging investment in priority and potentially competitive export growth industry;

- Ensuring labor is wage competitive by reducing public/private sector wage differentials;

- Increasing labor productivity and competitiveness;

- Making land more readily available for sound development and as collateral for financing;

- Developing a business-enabling regulatory environment; focusing support on competitive tradable goods and services

So far, implementation has been held back by the difficulties in coordinating policies across the states and national governments. The Economic Policy Implementation Council (EPIC), composed of national and state executive and legislative leaders, was established to push the reform policies and monitor their implementation. However, the EPIC lacks the legal authority to push states to enact the reforms. As a result, progress in the areas of tax, public sector, labor and land reform remains slow. Some progress, however, has been made at the micro level, such as in upgrading the secured transaction and bankruptcy legislations and easing some regulations for business.

Source: Federated States of Micronesia: Towards a Self-Sustainable Economy, Asian Development Bank.

41. It is too early to assess the impact of the new bankruptcy law on the efficiency of closing a business. The law, passed in 2006, represents a positive step towards establishing a process for orderly and equitable resolution of creditor claims against a debtor. Its impact on reducing the time and cost of bankruptcy and raising recovery rates for failed businesses has yet to be determined since as of October 2006, only one bankruptcy case had been filed under the new law. ${ }^{16}$ Further bankruptcy reforms should focus on increasing the recovery rate which is very low, even by regional standards (3.1 percent vs. the average of 27 percent for poor countries). Based on international experience (see below), further streamlining of court procedures and finding the appropriate balance between the rights of creditors and debtors would help improve the efficiency of bankruptcy and boost recovery rates.

\footnotetext{
${ }^{16}$ Some legal observers expressed concerns that the law grants the states too much power to exempt property from receivership, thereby reducing the influence of creditors and lowering recovery rates.
} 


\section{Box 4. Recent Reforms in Closing a Business in Selected Countries}

Recent reforms in closing a business in other countries focused on reducing delays in bankruptcy, improving the regulation of administrators, and giving more power to the creditors. For example, Serbia in 2005-06 set strict time limits and strengthened accountability standard for bankruptcy administrators. As a result, the average time for bankruptcy fell from seven years to less than three, while the recovery rate for creditors increased by 45 percent. Greater supervision of administrators also helped to cut down on misconduct in the proceedings. Serbia also created a new agency to supervise administrators, established ethical standards for the profession, and required administrators to pass an examination.

Finding the right balance between the rights of creditors and debtors could boost recovery rates. In Slovakia, the old law gave creditors only a limited role in the bankruptcy process. Businesses often did not enter bankruptcy until it was too late, and when they did so, the process could take as long as five years. The new reforms allowed creditors to form a committee representing their interests and shortened the time limits which helped to speed up bankruptcy by at least 9 months. Recovery rates also increased by 5 percentage points, to 48 cents on the dollar.

Another recent trend is to limit appeals. In many countries unnecessary multiple appeals are a major source of delay. For example, in India an appeal on the initiation of enforcement proceedings could delay the process for up to a year, leading to a fall in recovery rates by as much as 15 cents on the dollar. Many countries are now exploring limiting appeals as a way of unblocking delays.

Source: Doing Business in 2007: How to Reform (World Bank and IFC).

42. The new Secured Transaction Act represents an important step in improving access to credit. The law, which took effect in October 2006, defines the legal rights and obligations of parties involved in borrowing against movable assets, such as equipment. It also created a web-based national registry for secured claims. These measures will help banks to expand their lending to groups who were previously denied credit because of the lack of fixed collateral. Further reforms could focus on expanding the national registry to include other credit information, such as on businesses and individuals, to help develop a credit reporting system like in other countries.

\section{In improving contract enforcement, the priority should be to enhance the}

capacity of the courts. The efficiency of the courts in processing cases is limited by the lack of specialized judges and outdated case log management systems. For example, Chuuk, Pohnpei and the national government have only two judges each with a long backlog of cases that range from the criminal to the corporate. With the recently introduced bankruptcy and secured transaction law, there will be an even greater need to enhance the capacity of the courts to handle the additional case work. Reforms, such as the introduction of bailiffs with limited legal authority, the creation of specialized commercial courts, simplified rules for small cases, and firm time limits on enforcement, have helped in other countries to improve the efficiency in enforcing contracts and could be considered in Micronesia. 


\section{Box 5. Recent Reforms in Enforcing Contracts in Selected Countries}

The introduction of private bailiffs has help reduce delays in contract enforcement. For example, to speed up enforcement, Slovakia required that commercial cases be enforced by private bailiffs who were granted some legal authority. Bulgaria and Macedonia also introduced private bailiffs but have restricted their operations to certain locations.

Specialized commercial courts and commercial divisions in high courts have improved efficiency. Countries that have specialized courts or specialized commercial sections in general courts are estimated to resolve commercial disputes 40 percent faster than countries that do not. For example, Georgia established specialized commercial sections in the courts that helped to reduce caseload times by 45 percent in 2004.

Source: Doing Business in 2007: How to Reform (World Bank and IFC).

44. Land reform remains a difficult but important issue in Micronesia. Although some progress has been made to free up land for business investment, deeply rooted customs and traditions continue to hold back comprehensive reform of the land tenure system. Land tenure in Micronesia is based on communal ownership, and land sales are prohibited by the constitutions of the four states. As part of the ADB Private Sector Development Program, land reform has focused on legislating land lease arrangements. Under the ADB program, the four states have changed their laws to allow leases of over 50 years. In addition, land surveys, valuation and titling continue to expand, despite limited resources. In many cases, however, the registration process is delayed by frequent disputes on land ownership and boundaries. The ADB project in Chuuk, for example, aims to complete its first registration within 10-12 years (BGSI, 2006, Consultant Report). Liberalizing land sales is likely to remain a politically and culturally sensitive issue.

45. In the meantime, land reform efforts could focus on the efficient enforcement of land lease mortgage laws. These new laws will significantly improve the access to land for business development. The lease term of 50 years is broadly considered an acceptable length of time for implementing a business plan. At the same time, clear land titling valuation would help reduce uncertainty in securing land lease mortgage contracts. Based on experience elsewhere, digitizing titling certificate and allowing for online registration and streamlined procedures would also facilitate property registration. 


\section{E. Attracting More Foreign Investment}

46. Compared to other PICs, Micronesia is more closed to external trade. The measured trade share of Micronesia (exports plus imports over GDP) is significantly below other PICs except for Samoa, Tonga, and Vanuatu. Although FDI data is not available, it is likely that foreign investment is also low. Despite the small presence, evidence does exists suggesting that foreign-owned businesses operating in Micronesia do contribute significantly to the economy. For example, according to the Foreign Investment Board of Pohnpei State, there are about 200 licensed foreign business entities operating in sectors such as service,

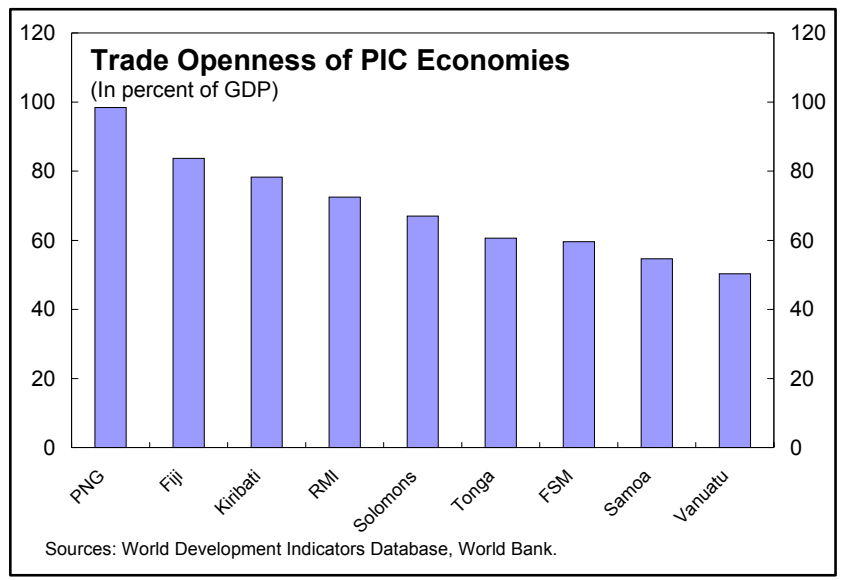
merchandise trade, tourism, construction and fishery, with a combined gross turnover exceeding \$10 million in 2003. These foreign businesses accounted for 6 percent of jobs in the state and contributed around 44 percent of the state tax revenue (2004 Investment Status Report).

\begin{tabular}{|c|c|c|c|c|c|c|c|c|c|}
\hline \multicolumn{10}{|c|}{ Contribution of Foreign Business to Job Creation and Tax Revenue in Pohnpei (as of end 2003) } \\
\hline & Services & $\begin{array}{l}\text { Merchandise } \\
\text { Trade }\end{array}$ & $\begin{array}{c}\text { Professional } \\
\text { Service }\end{array}$ & Fishery & Tourism & Construction & Other & Total & $\begin{array}{l}\text { Percent of Total } \\
\text { Employment } \\
\text { and Tax Revenue }\end{array}$ \\
\hline $\begin{array}{l}\text { Number of jobs created } \\
\text { Contribution to taxes } \\
\text { (in thousands of U.S.\$) }\end{array}$ & $\begin{array}{c}180 \\
2,200\end{array}$ & $\begin{array}{l}25 \\
600\end{array}$ & $\begin{array}{l}28 \\
200\end{array}$ & $\begin{array}{c}14 \\
100\end{array}$ & $\begin{array}{l}105 \\
200\end{array}$ & $\begin{array}{l}60 \\
100\end{array}$ & $\begin{array}{c}5 \\
100\end{array}$ & $\begin{array}{r}417 \\
3500\end{array}$ & $\begin{array}{r}5.9 \\
43.8\end{array}$ \\
\hline
\end{tabular}

47. Foreign investment is held back by the restrictive regime at the state level. Some problems include:

- With foreign investment regulated at state level, licensing procedures lack uniformity. This makes the regime prohibitively cumbersome for potential foreign investors looking to start a business across all four states. This has in turn restricted the size and type of foreign investment that would come to Micronesia.

- $\quad$ The conditions for approving foreign investment are strict. State regulations prohibit foreign investment in certain sectors and set minimum local or maximum foreign equity requirements, conditions for local employment, export requirements and other criteria. For example, Pohnpei prohibits foreign investment in the retail sector and allows up to 40 percent of foreign equity in mining, logging, and services (except professional and tourism). It also sets criteria regarding the extent to which a prospective foreign business will increase exports or decrease imports and gives preference to local workers. These measures in part reflect protectionist sentiment by 
local businesses who argue that only those business lines requiring capital and technology that are not available locally be open to foreign investors.

- $\quad$ The wide discretion of the foreign investment boards in granting a foreign investment permit clouds the transparency of the approval system. The criteria for approving state foreign investment permits are not spelled out in clear terms. Whether a foreign applicant meets the criteria or not depends very much on the discretion of the foreign investment boards, whose members are selected mainly among the local business community (The Richard Caldwell Consultant Report). ${ }^{17}$

48. With donors' assistance, some progress has been made in upgrading the foreign investment laws and regulations. In the late 1990s, the Foreign Investment Advisory Service, sponsored by the International Finance Corporation and the World Bank, conducted two reviews of the foreign investment regime and proposed a "spotlight" system with red, amber and green lists for foreign investments. ${ }^{18}$ In 2000, the ADB made reform of foreign investment laws and regulations by the five governments of Micronesia a condition for the second tranche of the private sector development loan. The objective was to streamline the application process and improve the consistency, transparency and fairness of the regulatory environment. By November 2005, the national, Kosrae and Yap governments had amended legislations to meet the condition, while Chuuk and Pohnpei had not.

\section{Liberalizing further the foreign investment regime would help attract much} needed capital and technology. Reforms such as moving to a "negative-list" system or "spotlight" for foreign investment would help to streamline the process and limit the risks of FIBs from being captured by narrow interests. Over the longer-term, centralizing the permit system across the four states so that foreign investors could do business in all of Micronesia with a single permit would help attract larger scale foreign investment.

\section{F. Conclusion}

50. Reforms to improve the business environment would help support private sector growth and development. Notwithstanding its difficult business environment, Micronesia faces a number of natural hurdles to developing further its private sector. However as demonstrated elsewhere and in the region, targeted reforms can significantly ease the cost of doing business and stimulate growth. Based on the Doing Business in 2007: How to Reform results, the priorities should be to strengthen the enforcement of contracts, expand land

\footnotetext{
${ }^{17}$ The FIB have argued that most of foreign investor applications are duly granted, e.g., 20 out of 23 were approved in 2004 in Pohnpei. However, it is also possible that many potential investors were turned away by the difficult requirements of the system.

${ }^{18}$ The red list defines the sectors that are prohibited to foreign investment. The amber list defines sectors that are open to foreign investment on clearly defined conditions. The green list defines sectors that are open to foreign investment without conditions.
} 
registration, reduce the time for closing a business, and improve access to credit. Expanding the capacity of the courts and streamlining procedures would strengthen contract enforcement and expedite bankruptcies. Building up a credit reporting system would improve access to financing for small businesses and households, while expanding land registration would facilitate the use of lease arrangements. At the same time, relaxing the restrictions on foreign investment would help attract much needed capital and technology. While challenging, evidence elsewhere, including in the region, shows that such reforms can help create a more vibrant and dynamic private sector and improve overall growth prospects. 


\section{REFERENCES}

BGSI, 2006, Consultant Report, Land Administration and Management Project in Micronesia, Asian Development Bank Technical Assistance Program.

Browne, Christopher,2006, "Pacific Island Economies," (Washington: International Monetary Fund).

Caldwell, Richard G., 2005, Consultant Report, Asian Development Bank Technical Assistance-4539 (FSM): Legislation for Private Sector Development (Manila: Asian Development Bank).

Foreign Investment Board of Pohnpei, 2004 Investment Status Report, 2004.

Hezel, Francis X. and Chris Lightfoot, 2005, "Myths of the Micronesian Economy", Micronesian Councilor, issue 59, (Pohnpei, Micronesian Seminar).

Holden, Paul, Malcom Bale and Sarah Holden, 2004, "Swimming Against the Tide? An Assessment of the Private Sector in the Pacific". (Manila: Asian Development Bank).

Lucas, Robert, 2005, Federated States of Micronesia 2005 Economic Report: "Towards a Self-sustainable Economy," (Manila: Asian Development Bank).

United States Government Accountability Office, 2006, Report to Congressional Committees on Compacts of Association: "Development Prospects Remain Limited for Micronesia and Marshall Islands," (Washington).

World Bank and International Finance Corporation, 2006, Doing Business Database (www.doingbusiness.org), Doing Business in 2007: How to Reform, (Washington: World Bank and IFC). 
Table 1. Federated States of Micronesia: Basic Data, FY2002-06 1/

\begin{tabular}{ll} 
Nominal GDP (FY2005): & US $\$ 237$ million \\
Population (FY2005): & 108,276 \\
GDP per capita (FY2005): & US $\$ 2,189$ \\
Quota: & SDR5.1 million \\
\hline
\end{tabular}

\begin{tabular}{|c|c|c|c|c|c|}
\hline & FY2002 & FY2003 & $\begin{array}{c}\text { FY2004 } \\
\text { Est. }\end{array}$ & $\begin{array}{c}\text { FY2005 } \\
\text { Est. }\end{array}$ & $\begin{array}{c}\text { FY2006 } \\
\text { Proj. }\end{array}$ \\
\hline \multicolumn{6}{|l|}{ Real sector (average annual percent change) } \\
\hline Real GDP & 1.4 & 3.3 & -4.4 & 1.5 & -0.7 \\
\hline Consumer prices & -0.1 & -0.2 & 1.8 & 4.1 & 3.9 \\
\hline Employment & 0.7 & -1.6 & -1.0 & 0.3 & 0.6 \\
\hline Public (including public enterprises) & 4.6 & -2.6 & -2.9 & 2.5 & 2.9 \\
\hline Private & -4.1 & 0.1 & 1.4 & -2.0 & -1.9 \\
\hline Nominal wages & 3.2 & 0.9 & -0.4 & 1.1 & 2.2 \\
\hline Public-private wage ratio & 1.9 & 1.9 & 2.0 & 2.0 & 2.0 \\
\hline \multicolumn{6}{|c|}{ Consolidated government finance (in percent of GDP) } \\
\hline Revenue and grants & 71.7 & 68.6 & 59.4 & 56.6 & 53.1 \\
\hline Revenue & 21.0 & 19.1 & 24.0 & 20.9 & 19.8 \\
\hline Grants & 50.6 & 49.5 & 35.4 & 35.7 & 33.4 \\
\hline Expenditure & 63.9 & 67.9 & 65.6 & 62.0 & 54.7 \\
\hline Current & 53.5 & 55.7 & 53.6 & 56.3 & 51.4 \\
\hline Capital & 10.4 & 12.2 & 12.0 & 5.7 & 3.3 \\
\hline Overall balance & 7.7 & 0.7 & -6.2 & -5.4 & -1.6 \\
\hline Usable financial assets $2 /$ & -2.5 & -3.5 & -1.3 & 2.5 & 1.6 \\
\hline excluding Yap and Pohnpei & -9.9 & -11.4 & -11.0 & -11.4 & -11.7 \\
\hline Compact Trust Fund (millions of U.S. dollars, er & & & 0.0 & 62.4 & 84.3 \\
\hline \multicolumn{6}{|c|}{ Commercial banks (in millions of U.S. dollars; end of period, through June 2006) } \\
\hline Foreign assets & 87.2 & 110.0 & 105.2 & 99.2 & 104.8 \\
\hline Loans & 39.1 & 23.7 & 21.3 & 25.7 & 29.0 \\
\hline Total deposits & 112.0 & 119.8 & 115.4 & 111.4 & 117.7 \\
\hline \multicolumn{6}{|l|}{ Interest rates (in percent, average for $\mathrm{FY}$ ) } \\
\hline Consumer loans & 15.3 & 15.1 & 15.1 & 16.4 & 19.2 \\
\hline Commercial loans & 6.2 & 6.9 & 6.9 & 7.8 & 10.4 \\
\hline \multicolumn{6}{|l|}{ Balance of payments (in millions of U.S. dollars) } \\
\hline Trade balance & -84.6 & -91.8 & -119.3 & -121.2 & -111.7 \\
\hline Net services and income & -25.3 & -24.1 & -21.0 & -21.4 & -22.1 \\
\hline Private and official transfers & 104.2 & 118.1 & 99.6 & 106.2 & 102.7 \\
\hline Current account including official transfers & -5.7 & 2.2 & -40.7 & -36.4 & -31.1 \\
\hline (in percent of GDP) & -2.5 & 0.9 & -18.1 & -15.3 & -12.7 \\
\hline Current account excluding official transfers & -107.6 & -113.6 & -137.8 & -139.3 & -128.5 \\
\hline (in percent of GDP) & -48.1 & -49.3 & -61.4 & -58.8 & -52.5 \\
\hline Overall balance $3 /$ & 32.1 & 18.3 & -55.5 & -20.8 & -14.1 \\
\hline (in percent of GDP) & 14.3 & 7.9 & -24.7 & -8.8 & -5.8 \\
\hline Gross reserves (in months of imports) & 4.7 & 6.3 & 3.5 & 3.1 & 3.0 \\
\hline \multicolumn{6}{|c|}{ External debt (in millions of U.S. dollars; end of period) $4 /$} \\
\hline Stock & 57.9 & 59.2 & 59.4 & 59.9 & 60.4 \\
\hline (in percent of GDP) & 25.9 & 25.7 & 26.5 & 25.3 & 24.7 \\
\hline Debt service & 2.4 & 2.4 & 2.6 & 2.5 & 2.5 \\
\hline (in percent of exports of goods and services) & 5.2 & 5.2 & 7.2 & 6.5 & 6.2 \\
\hline Exchange rate regime & \multicolumn{5}{|c|}{ U.S. dollar is the official currency } \\
\hline
\end{tabular}

Sources: Data provided by the Micronesian authorities and Fund staff estimates.

1/ Fiscal year ending September 30.

2/ Cash and other liquid investments not reserved for specific uses.

$3 /$ Includes changes in reserves, valuation changes and errors and omissions.

4/ Government and public enterprise debt only. 
Table 2. Federated State of Micronesia: Gross Domestic Product, FY2001-06 1/

\begin{tabular}{|c|c|c|c|c|c|c|}
\hline & FY2001 & FY2002 & FY2003 & FY2004 & FY2005 & $\begin{array}{r}\text { FY2006 } \\
\text { Est. }\end{array}$ \\
\hline & \multicolumn{6}{|c|}{ (in million U.S. dollars) } \\
\hline Productive enterprises & 80.2 & 80.3 & 85.4 & 81.7 & 85.3 & 86.0 \\
\hline Private sector & 65.3 & 64.0 & 66.0 & 65.5 & 67.7 & 67.5 \\
\hline Public enterprises & 14.8 & 16.2 & 19.4 & 16.2 & 17.6 & 18.5 \\
\hline Financial enterprises & 8.5 & 7.7 & 4.7 & 5.0 & 6.1 & 6.3 \\
\hline Government & 64.9 & 69.4 & 69.4 & 67.6 & 70.9 & 74.5 \\
\hline Non-profit organizations & 2.3 & 2.5 & 2.4 & 2.5 & 2.6 & 2.6 \\
\hline Households & 54.9 & 54.9 & 54.9 & 54.3 & 57.7 & 60.6 \\
\hline Subsistence & 33.2 & 33.3 & 33.3 & 32.4 & 34.7 & 36.8 \\
\hline Home ownership & 21.6 & 21.6 & 21.5 & 21.9 & 22.9 & 23.8 \\
\hline Indirect taxes & 19.1 & 17.4 & 19.1 & 18.5 & 21.2 & 21.6 \\
\hline less bank service charge & -9.0 & -8.4 & -5.4 & -5.2 & -6.7 & -7.0 \\
\hline \multirow[t]{2}{*}{ Nominal GDP } & 220.9 & 223.7 & 230.4 & 224.4 & 237.0 & 244.7 \\
\hline & \multicolumn{6}{|c|}{ (In percent of GDP) } \\
\hline Productive enterprises & 36.3 & 35.9 & 37.1 & 36.4 & 36.0 & 35.1 \\
\hline Financial enterprises & 3.9 & 3.4 & 2.0 & 2.2 & 2.6 & 2.6 \\
\hline Government & 29.4 & 31.0 & 30.1 & 30.1 & 29.9 & 30.5 \\
\hline Nonprofit organizations & 1.1 & 1.1 & 1.0 & 1.1 & 1.1 & 1.1 \\
\hline Households & 24.8 & 24.5 & 23.8 & 24.2 & 24.3 & 24.8 \\
\hline \multicolumn{7}{|l|}{ Memorandum items: } \\
\hline Nominal GDP per capita (in U.S. dollars) & 2059 & 2080 & 2138 & 2077 & 2189 & 2254 \\
\hline Real GDP growth rate (in percent) & 0.4 & 1.4 & 3.3 & -4.4 & 1.5 & -0.7 \\
\hline Real GDP (in FY98 millions U.S. dollars) & 209.7 & 212.6 & 219.6 & 210.0 & 213.2 & 211.8 \\
\hline
\end{tabular}

Sources: Data provided by the Micronesian authorities and Fund staff estimates.

1/ Fiscal year ending September 30. 


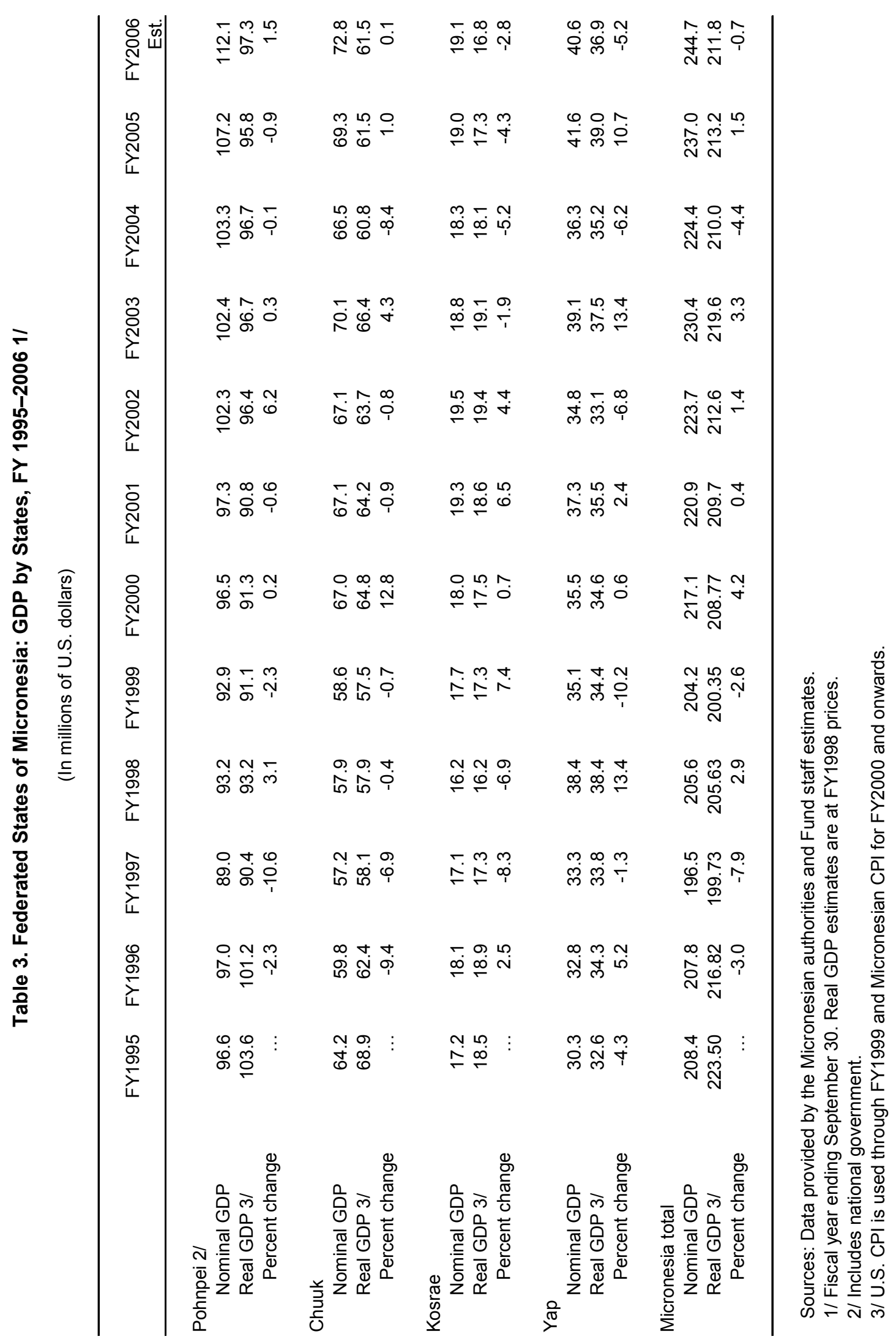


Table 4. Federated States of Micronesia: Public and Private Sector Employment and Wages, FY 2001-06 1/

\begin{tabular}{|c|c|c|c|c|c|c|}
\hline & FY2001 & FY2002 & FY2003 & FY2004 & FY2005 & $\begin{array}{r}\text { FY2006 } \\
\text { Est. }\end{array}$ \\
\hline & \multicolumn{6}{|c|}{ (In persons) } \\
\hline Total employment & 16,607 & 16,726 & 16,459 & 16,300 & 16,349 & 16,454 \\
\hline Total public sector & 7,579 & 7,940 & 7,624 & 7,282 & 7,461 & 7,806 \\
\hline National and state government & 5,797 & 5,949 & 5,704 & 5,645 & 5,976 & 6,480 \\
\hline National government & 877 & 874 & 890 & 886 & 694 & 681 \\
\hline Pohnpei & 1,181 & 1,216 & 1,207 & 1,221 & 1,253 & 1,376 \\
\hline Chuuk & 2,374 & 2,464 & 2,173 & 2,111 & 2,298 & 2,741 \\
\hline Yap & 737 & 745 & 773 & 762 & 1,049 & 1,000 \\
\hline Kosrae & 629 & 651 & 661 & 665 & 681 & 682 \\
\hline Municipalities & 872 & 1,117 & 1,051 & 789 & 740 & 622 \\
\hline Public enterprises & 910 & 874 & 869 & 849 & 745 & 704 \\
\hline Private sector & 7,222 & 6,929 & 6,939 & 7,039 & 6,901 & 6,766 \\
\hline Private Nonfinancial enterprises & 6,493 & 6,182 & 6,230 & 6,339 & 6,221 & 6,094 \\
\hline \multicolumn{7}{|l|}{ Of which: } \\
\hline Wholesale and retail trade & 2,717 & 2,777 & 2,912 & 3,034 & 3,167 & 3,210 \\
\hline Transport & 1,008 & 961 & 1,060 & 1,037 & 1,055 & 1,061 \\
\hline Education & 916 & 1,061 & 1,109 & 1,170 & 1,182 & 1,154 \\
\hline Construction & 1,102 & 882 & 797 & 825 & 883 & 807 \\
\hline Hotels and restaurants & 863 & 762 & 761 & 808 & 818 & 797 \\
\hline Manufacturing & 819 & 793 & 680 & 589 & 184 & 79 \\
\hline Financial institutions & 207 & 201 & 175 & 176 & 188 & 194 \\
\hline Nonprofit organizations & 523 & 545 & 534 & 525 & 491 & 479 \\
\hline & \multicolumn{6}{|c|}{ (In U.S. dollars) } \\
\hline \multicolumn{7}{|l|}{ Average public sector wage } \\
\hline National and state government & 9,965 & 10,682 & 10,293 & 10,172 & 11,129 & 11,036 \\
\hline Municipalities & 3,989 & 3,805 & 3,823 & 4,038 & 4,695 & 5,204 \\
\hline Public enterprises & 10,505 & 10,486 & 10,661 & 10,936 & 11,434 & 12,816 \\
\hline Average private sector wage & 3,989 & 4,084 & 4,169 & 4,135 & 4,112 & 4,129 \\
\hline Financial enterprises & 15,549 & 15,376 & 16,135 & 13,985 & 13,521 & 14,049 \\
\hline Nonprofit organizations & 4,234 & 4,314 & 4,281 & 4,470 & 4,938 & 5,199 \\
\hline \multicolumn{7}{|l|}{ Memorandum item: } \\
\hline Total population & 107,403 & 108,012 & 108,826 & 109,691 & 110,487 & 111,183 \\
\hline
\end{tabular}

Sources: Data provided by the Micronesian authorities and Fund staff estimates.

1/ Fiscal year ending September 30 . 
Table 5. Federated States of Micronesia: Consumer Price Index, 2000-06

\begin{tabular}{|c|c|c|c|c|c|c|c|c|c|}
\hline & & Total & Food & $\begin{array}{c}\text { Tob, Alch, } \\
\text { Betelnut, } \\
\text { Sakau }\end{array}$ & $\begin{array}{l}\text { Clothing, } \\
\text { Footwear }\end{array}$ & Housing & $\begin{array}{c}\text { Fuel, Light \& } \\
\text { Water }\end{array}$ & Services & Miscellaneous \\
\hline & Weight & 100 & 45.5 & 8.5 & 2.9 & 2.7 & 5.6 & 16.5 & 18.4 \\
\hline & & \multicolumn{8}{|c|}{$(2000=100)$} \\
\hline \multirow[t]{4}{*}{2000} & Qtr 1 & 100.8 & 100.7 & 100.0 & 101.3 & 102.0 & 100.6 & 100.2 & 101.7 \\
\hline & Qtr 2 & 102.0 & 100.7 & 101.7 & 100.5 & 101.9 & 116.8 & 101.9 & 101.1 \\
\hline & Qtr 3 & 102.5 & 100.9 & 103.1 & 97.0 & 99.7 & 117.0 & 107.3 & 99.0 \\
\hline & Qtr 4 & 103.3 & 101.2 & 103.8 & 98.0 & 100.4 & 118.0 & 109.0 & 100.1 \\
\hline \multirow[t]{4}{*}{2001} & Qtr 1 & 102.8 & 100.6 & 103.4 & 96.8 & 99.6 & 112.6 & 110.5 & 99.7 \\
\hline & Qtr 2 & 102.6 & 100.3 & 103.7 & 96.6 & 100.1 & 111.2 & 110.5 & 99.5 \\
\hline & Qtr 3 & 102.5 & 100.4 & 105.4 & 96.6 & 98.7 & 113.2 & 111.8 & 95.9 \\
\hline & Qtr 4 & 102.7 & 100.9 & 101.8 & 96.2 & 98.5 & 119.2 & 112.5 & 95.4 \\
\hline \multirow[t]{4}{*}{2002} & Qtr 1 & 102.8 & 101.7 & 97.2 & 97.0 & 99.8 & 123.2 & 111.8 & 95.4 \\
\hline & Qtr 2 & 102.7 & 101.2 & 99.7 & 96.5 & 99.1 & 120.5 & 112.4 & 95.4 \\
\hline & Qtr 3 & 102.4 & 100.7 & 99.7 & 95.7 & 98.6 & 120.5 & 112.0 & 95.3 \\
\hline & Qtr 4 & 102.3 & 99.8 & 100.9 & 95.4 & 99.3 & 123.6 & 112.1 & 95.4 \\
\hline \multirow[t]{4}{*}{2003} & Qtr 1 & 102.0 & 99.3 & 98.9 & 95.9 & 97.1 & 125.0 & 112.5 & 95.5 \\
\hline & Qtr 2 & 102.6 & 100.5 & 97.9 & 95.9 & 97.0 & 125.0 & 113.3 & 95.7 \\
\hline & Qtr 3 & 102.7 & 100.4 & 98.3 & 97.0 & 96.6 & 126.8 & 113.1 & 95.8 \\
\hline & Qtr 4 & 103.5 & 101.0 & 97.4 & 97.0 & 96.7 & 134.5 & 113.4 & 96.1 \\
\hline \multirow[t]{4}{*}{2004} & Qtr 1 & 103.9 & 102.8 & 95.1 & 96.6 & 97.0 & 134.3 & 116.0 & 92.9 \\
\hline & Qtr 2 & 104.5 & 104.8 & 93.3 & 95.2 & 96.7 & 137.6 & 116.1 & 91.1 \\
\hline & Qtr 3 & 105.2 & 105.7 & 93.0 & 95.6 & 97.2 & 137.7 & 117.4 & 91.3 \\
\hline & Qtr 4 & 106.8 & 106.1 & 90.9 & 95.9 & 97.7 & 154.7 & 120.5 & 92.1 \\
\hline \multirow[t]{4}{*}{2005} & Qtr 1 & 108.0 & 106.6 & 96.5 & 95.9 & 98.7 & 161.4 & 121.2 & 92.1 \\
\hline & Qtr 2 & 108.9 & 107.5 & 98.7 & 95.7 & 98.8 & 164.4 & 122.4 & 91.6 \\
\hline & Qtr 3 & 110.4 & 108.5 & 100.7 & 96.8 & 99.0 & 174.3 & 123.3 & 92.2 \\
\hline & Qtr 4 & 110.9 & 107.5 & 101.2 & 96.5 & 99.0 & 187.5 & 124.9 & 92.2 \\
\hline \multirow[t]{2}{*}{2006} & Qtr 1 & 112.2 & 109.1 & 102.8 & 97.1 & 100.5 & 187.4 & 127.1 & 92.2 \\
\hline & & \multicolumn{8}{|c|}{ (Four-quarter percent change) } \\
\hline \multirow[t]{4}{*}{2003} & Qtr 1 & -0.8 & -2.3 & 1.8 & -1.1 & -2.6 & 1.5 & 0.6 & 0.1 \\
\hline & Qtr 2 & -0.1 & -0.7 & -1.9 & -0.6 & -2.1 & 3.7 & 0.8 & 0.3 \\
\hline & Qtr 3 & 0.3 & -0.3 & -1.4 & 1.4 & -2.1 & 5.2 & 0.9 & 0.5 \\
\hline & Qtr 4 & 1.1 & 1.1 & -3.5 & 1.6 & -2.7 & 8.7 & 1.2 & 0.8 \\
\hline \multirow[t]{4}{*}{2004} & Qtr 1 & 1.9 & 3.5 & -3.9 & 0.7 & -0.1 & 7.4 & 3.1 & -2.7 \\
\hline & Qtr 2 & 1.8 & 4.3 & -4.6 & -0.7 & -0.3 & 10.1 & 2.5 & -4.8 \\
\hline & Qtr 3 & 2.4 & 5.3 & -5.5 & -1.4 & 0.7 & 8.6 & 3.9 & -4.7 \\
\hline & Qtr 4 & 3.2 & 5.1 & -6.7 & -1.1 & 1.1 & 15.0 & 6.3 & -4.1 \\
\hline \multirow[t]{4}{*}{2005} & Qtr 1 & 3.9 & 3.7 & 1.5 & -0.7 & 1.8 & 20.1 & 4.5 & -0.9 \\
\hline & Qtr 2 & 4.2 & 2.6 & 5.7 & 0.5 & 2.1 & 19.4 & 5.4 & 0.5 \\
\hline & Qtr 3 & 4.9 & 2.6 & 8.4 & 1.2 & 1.8 & 26.6 & 5.0 & 1.0 \\
\hline & Qtr 4 & 3.9 & 1.3 & 11.3 & 0.6 & 1.3 & 21.2 & 3.6 & 0.1 \\
\hline 2006 & Qtr 1 & 3.9 & 2.4 & 6.5 & 1.2 & 1.8 & 16.2 & 4.8 & 0.1 \\
\hline
\end{tabular}

Source: Data provided by the Micronesian authorities. 
Table 6. Federated States of Micronesia: Pohnpei Consumer Price Index, 2000-06

\begin{tabular}{|c|c|c|c|c|c|c|c|c|c|}
\hline & & Total & Food & $\begin{array}{c}\text { Tob, Alch, } \\
\text { Betelnut, } \\
\text { Sakau }\end{array}$ & $\begin{array}{l}\text { Clothing, } \\
\text { Footwear }\end{array}$ & Housing & $\begin{array}{c}\text { Fuel, Light \& } \\
\text { Water }\end{array}$ & Services & Miscellaneous \\
\hline & Weight & 37.5 & 16.2 & 3.5 & 1.1 & 1.2 & 2.7 & 5.5 & 7.3 \\
\hline & & \multicolumn{8}{|c|}{$(2000=100)$} \\
\hline \multirow[t]{4}{*}{2000} & Qtr 1 & 101.4 & 101.0 & 99.9 & 100.9 & 103.1 & 99.9 & 99.9 & 104.6 \\
\hline & Qtr 2 & 103.2 & 104.1 & 98.6 & 100.8 & 102.9 & 106.8 & 101.1 & 104.1 \\
\hline & Qtr 3 & 104.5 & 103.6 & 98.6 & 95.8 & 99.3 & 106.8 & 118.5 & 100.0 \\
\hline & Qtr 4 & 104.3 & 103.6 & 98.6 & 95.8 & 99.3 & 106.8 & 118.5 & 99.1 \\
\hline \multirow[t]{4}{*}{2001} & Qtr 1 & 104.4 & 103.0 & 98.2 & 95.9 & 98.6 & 113.2 & 118.7 & 99.0 \\
\hline & Qtr 2 & 104.4 & 103.0 & 98.1 & 95.9 & 98.8 & 110.4 & 118.6 & 99.9 \\
\hline & Qtr 3 & 102.5 & 101.6 & 96.6 & 96.9 & 98.6 & 110.8 & 120.4 & 92.3 \\
\hline & Qtr 4 & 102.8 & 103.6 & 92.4 & 95.4 & 98.4 & 105.1 & 122.2 & 92.3 \\
\hline \multirow[t]{4}{*}{2002} & Qtr 1 & 103.7 & 105.0 & 90.1 & 97.4 & 100.0 & 112.4 & 121.6 & 92.0 \\
\hline & Qtr 2 & 102.6 & 103.2 & 89.8 & 96.9 & 100.2 & 106.1 & 123.2 & 92.0 \\
\hline & Qtr 3 & 102.6 & 103.1 & 90.9 & 95.0 & 99.4 & 108.1 & 122.1 & 92.1 \\
\hline & Qtr 4 & 102.0 & 101.0 & 92.7 & 94.1 & 99.4 & 110.7 & 122.1 & 92.2 \\
\hline \multirow[t]{4}{*}{2003} & Qtr 1 & 102.2 & 101.0 & 92.7 & 95.7 & 100.1 & 111.3 & 122.2 & 92.4 \\
\hline & Qtr 2 & 103.4 & 103.4 & 92.7 & 96.0 & 100.2 & 111.9 & 122.3 & 92.7 \\
\hline & Qtr 3 & 103.1 & 103.1 & 92.4 & 98.5 & 100.2 & 111.9 & 122.0 & 92.2 \\
\hline & Qtr 4 & 102.8 & 102.8 & 91.8 & 98.3 & 100.2 & 111.9 & 122.1 & 91.5 \\
\hline \multirow[t]{4}{*}{2004} & Qtr 1 & 103.3 & 107.5 & 93.2 & 98.8 & 100.2 & 110.9 & 122.5 & 82.7 \\
\hline & Qtr 2 & 104.2 & 108.2 & 93.2 & 98.8 & 100.1 & 117.6 & 123.4 & 82.8 \\
\hline & Qtr 3 & 104.2 & 108.2 & 93.2 & 98.8 & 100.1 & 117.6 & 123.4 & 82.8 \\
\hline & Qtr 4 & 106.0 & 109.2 & 91.4 & 98.4 & 100.1 & 128.0 & 126.3 & 84.9 \\
\hline \multirow[t]{4}{*}{2005} & Qtr 1 & 107.6 & 111.0 & 96.1 & 98.4 & 100.5 & 132.4 & 127.0 & 84.9 \\
\hline & Qtr 2 & 109.3 & 112.8 & 100.8 & 98.3 & 100.8 & 136.7 & 127.6 & 84.9 \\
\hline & Qtr 3 & 110.9 & 114.5 & 105.5 & 98.2 & 101.2 & 141.0 & 128.2 & 85.0 \\
\hline & Qtr 4 & 111.0 & 114.6 & 105.4 & 97.6 & 101.2 & 141.6 & 128.5 & 85.1 \\
\hline \multirow[t]{2}{*}{2006} & Qtr 1 & 110.9 & 114.3 & 106.3 & 98.1 & 103.2 & 141.3 & 128.0 & 85.0 \\
\hline & & \multicolumn{8}{|c|}{ (Four-quarter percent change) } \\
\hline \multirow[t]{4}{*}{2003} & Qtr 1 & -1.4 & -3.9 & 3.0 & -1.7 & 0.0 & -1.0 & 0.5 & 0.4 \\
\hline & Qtr 2 & 0.8 & 0.2 & 3.3 & -0.9 & 0.0 & 5.4 & -0.7 & 0.8 \\
\hline & Qtr 3 & 0.6 & 0.1 & 1.6 & 3.7 & 0.8 & 3.5 & -0.1 & 0.1 \\
\hline & Qtr 4 & 0.8 & 1.8 & -1.1 & 4.4 & 0.8 & 1.1 & 0.0 & -0.7 \\
\hline \multirow[t]{4}{*}{2004} & Qtr 1 & 1.0 & 6.5 & 0.5 & 3.2 & 0.1 & -0.4 & 0.2 & -10.5 \\
\hline & Qtr 2 & 0.8 & 4.6 & 0.5 & 2.9 & -0.1 & 5.1 & 0.8 & -10.7 \\
\hline & Qtr 3 & 1.0 & 5.0 & 0.8 & 0.3 & -0.1 & 5.1 & 1.1 & -10.2 \\
\hline & Qtr 4 & 3.1 & 6.2 & -0.4 & 0.2 & -0.1 & 14.4 & 3.5 & -7.3 \\
\hline \multirow[t]{4}{*}{2005} & Qtr 1 & 4.3 & 3.2 & 3.1 & -0.4 & 0.3 & 19.4 & 3.7 & 2.6 \\
\hline & Qtr 2 & 4.9 & 4.2 & 8.2 & -0.5 & 0.7 & 16.2 & 3.4 & 2.5 \\
\hline & Qtr 3 & 6.5 & 5.8 & 13.2 & -0.5 & 1.1 & 19.9 & 3.9 & 2.7 \\
\hline & Qtr 4 & 4.7 & 5.0 & 15.3 & -0.9 & 1.1 & 10.6 & 1.7 & 0.3 \\
\hline 2006 & Qtr 1 & 3.1 & 3.0 & 10.7 & -0.3 & 2.7 & 6.8 & 0.8 & 0.2 \\
\hline
\end{tabular}

Source: Data provided by the Micronesian authorities. 
Table 7. Federated States of Micronesia: Chuuk Consumer Price Index, 2000-06

\begin{tabular}{|c|c|c|c|c|c|c|c|c|c|}
\hline & & Total & Food & $\begin{array}{l}\text { Tob, Alch, } \\
\text { Betelnut, } \\
\text { Sakau }\end{array}$ & $\begin{array}{l}\text { Clothing, } \\
\text { Footwear }\end{array}$ & Housing & $\begin{array}{c}\text { Fuel, Light \& } \\
\text { Water }\end{array}$ & Services & Miscellaneous \\
\hline & Weight & 41.6 & 22.0 & 2.8 & 1.1 & 0.9 & 1.9 & 6.7 & 6.1 \\
\hline & & \multicolumn{8}{|c|}{$(2000=100)$} \\
\hline \multirow[t]{4}{*}{2000} & Qtr 1 & 100.4 & 100.4 & 100.4 & 101.2 & 101.4 & 102.0 & 100.1 & 100.0 \\
\hline & Qtr 2 & 101.5 & 98.0 & 106.5 & 100.4 & 101.4 & 139.6 & 101.9 & 99.8 \\
\hline & Qtr 3 & 101.4 & 98.6 & 109.3 & 96.3 & 99.6 & 139.6 & 100.6 & 98.2 \\
\hline & Qtr 4 & 103.1 & 99.2 & 111.1 & 98.4 & 101.5 & 142.8 & 104.6 & 100.9 \\
\hline \multirow[t]{4}{*}{2001} & Qtr 1 & 101.7 & 99.0 & 109.4 & 96.6 & 100.8 & 116.3 & 105.2 & 100.7 \\
\hline & Qtr 2 & 100.9 & 98.0 & 107.7 & 96.4 & 101.2 & 116.3 & 105.3 & 99.5 \\
\hline & Qtr 3 & 102.3 & 99.5 & 113.6 & 95.9 & 100.0 & 121.8 & 106.4 & 98.2 \\
\hline & Qtr 4 & 102.9 & 98.9 & 111.4 & 96.1 & 99.8 & 149.2 & 106.1 & 97.2 \\
\hline \multirow[t]{4}{*}{2002} & Qtr 1 & 102.6 & 99.8 & 100.7 & 97.1 & 101.7 & 150.6 & 105.1 & 97.6 \\
\hline & Qtr 2 & 103.4 & 100.4 & 108.6 & 96.2 & 99.7 & 150.6 & 105.2 & 97.3 \\
\hline & Qtr 3 & 103.0 & 99.9 & 108.6 & 96.2 & 99.6 & 147.8 & 105.1 & 97.6 \\
\hline & Qtr 4 & 103.3 & 99.6 & 109.4 & 96.4 & 101.8 & 153.3 & 105.1 & 97.7 \\
\hline \multirow{4}{*}{2003} & Qtr 1 & 102.7 & 98.7 & 105.9 & 96.0 & 94.3 & 156.5 & 105.9 & 97.9 \\
\hline & Qtr 2 & 103.3 & 99.5 & 101.8 & 96.0 & 94.0 & 159.3 & 107.6 & 98.4 \\
\hline & Qtr 3 & 103.5 & 99.2 & 103.5 & 96.2 & 92.5 & 164.8 & 107.4 & 98.8 \\
\hline & Qtr 4 & 105.6 & 100.7 & 103.5 & 96.4 & 93.5 & 187.6 & 107.7 & 100.3 \\
\hline \multirow[t]{4}{*}{2004} & Qtr 1 & 106.3 & 101.1 & 95.2 & 95.3 & 93.9 & 188.6 & 113.7 & 100.6 \\
\hline & Qtr 2 & 106.9 & 104.1 & 88.6 & 95.4 & 92.6 & 188.6 & 114.8 & 96.2 \\
\hline & Qtr 3 & 108.3 & 106.0 & 88.8 & 94.8 & 92.9 & 188.6 & 116.5 & 96.7 \\
\hline & Qtr 4 & 109.6 & 105.7 & 87.8 & 94.8 & 93.3 & 212.4 & 119.3 & 97.1 \\
\hline \multirow[t]{4}{*}{2005} & Qtr 1 & 109.8 & 105.2 & 89.4 & 94.9 & 93.9 & 214.7 & 120.3 & 97.1 \\
\hline & Qtr 2 & 109.9 & 105.7 & 89.4 & 94.4 & 93.9 & 214.7 & 120.3 & 96.4 \\
\hline & Qtr 3 & 111.2 & 106.0 & 88.3 & 95.1 & 93.4 & 235.8 & 120.7 & 97.6 \\
\hline & Qtr 4 & 112.2 & 104.0 & 89.0 & 95.0 & 93.4 & 272.5 & 123.0 & 97.6 \\
\hline \multirow[t]{2}{*}{2006} & Qtr 1 & 115.3 & 107.5 & 92.5 & 95.3 & 94.1 & 272.5 & 129.1 & 97.8 \\
\hline & & \multicolumn{8}{|c|}{ (Four-quarter percent change) } \\
\hline \multirow[t]{4}{*}{2003} & Qtr 1 & 0.0 & -1.1 & 5.1 & -1.1 & -7.3 & 4.0 & 0.7 & 0.3 \\
\hline & Qtr 2 & -0.1 & -0.9 & -6.2 & -0.3 & -5.6 & 5.8 & 2.3 & 1.1 \\
\hline & Qtr 3 & 0.5 & -0.7 & -4.7 & -0.1 & -7.1 & 11.5 & 2.2 & 1.3 \\
\hline & Qtr 4 & 2.3 & 1.1 & -5.4 & 0.1 & -8.2 & 22.4 & 2.5 & 2.6 \\
\hline \multirow[t]{4}{*}{2004} & Qtr 1 & 3.5 & 2.4 & -10.1 & -0.8 & -0.4 & 20.5 & 7.4 & 2.8 \\
\hline & Qtr 2 & 3.5 & 4.6 & -13.0 & -0.6 & -1.5 & 18.4 & 6.7 & -2.2 \\
\hline & Qtr 3 & 4.6 & 6.8 & -14.2 & -1.4 & 0.4 & 14.4 & 8.4 & -2.1 \\
\hline & Qtr 4 & 3.8 & 4.9 & -15.2 & -1.6 & -0.2 & 13.2 & 10.8 & -3.2 \\
\hline \multirow[t]{4}{*}{2005} & Qtr 1 & 3.3 & 4.1 & -6.1 & -0.4 & 0.0 & 13.9 & 5.8 & -3.5 \\
\hline & Qtr 2 & 2.8 & 1.5 & 0.9 & -0.9 & 1.4 & 13.9 & 4.8 & 0.2 \\
\hline & Qtr 3 & 2.7 & 0.0 & -0.6 & 0.3 & 0.5 & 25.1 & 3.6 & 0.9 \\
\hline & Qtr 4 & 2.4 & -1.5 & 1.5 & 0.2 & 0.0 & 28.3 & 3.1 & 0.6 \\
\hline 2006 & Qtr 1 & 5.0 & 2.1 & 3.5 & 0.4 & 0.2 & 26.9 & 7.3 & 0.7 \\
\hline
\end{tabular}

Source: Data provided by the Micronesian authorities. 
Table 8. Federated States of Micronesia: Kosrae Consumer Price Index, 2000-06

\begin{tabular}{|c|c|c|c|c|c|c|c|c|c|}
\hline & & Total & Food & $\begin{array}{c}\text { Tob, Alch, } \\
\text { Betelnut, } \\
\text { Sakau }\end{array}$ & $\begin{array}{l}\text { Clothing, } \\
\text { Footwear }\end{array}$ & Housing & $\begin{array}{c}\text { Fuel, Light \& } \\
\text { Water }\end{array}$ & Services & Miscellaneous \\
\hline & Weight & 6.0 & 2.5 & 0.2 & 0.4 & 0.1 & 0.2 & 1.3 & 1.4 \\
\hline & & \multicolumn{8}{|c|}{$(2000=100)$} \\
\hline \multirow[t]{4}{*}{2000} & Qtr 1 & 101.1 & 101.0 & 102.7 & 105.1 & 103.9 & 100.2 & 100.2 & 100.8 \\
\hline & Qtr 2 & 101.2 & 101.2 & 101.5 & 105.1 & 103.8 & 99.5 & 100.3 & 101.3 \\
\hline & Qtr 3 & 101.4 & 101.7 & 104.2 & 105.0 & 103.7 & 99.5 & 99.4 & 101.6 \\
\hline & Qtr 4 & 101.9 & 102.5 & 104.2 & 106.9 & 104.0 & 99.5 & 99.2 & 101.8 \\
\hline \multirow[t]{4}{*}{2001} & Qtr 1 & 101.8 & 99.9 & 102.0 & 102.0 & 102.3 & 99.5 & 103.6 & 103.6 \\
\hline & Qtr 2 & 101.3 & 99.6 & 102.0 & 102.2 & 102.8 & 99.5 & 104.0 & 101.9 \\
\hline & Qtr 3 & 100.7 & 98.8 & 104.5 & 101.8 & 95.3 & 99.2 & 103.6 & 101.0 \\
\hline & Qtr 4 & 100.4 & 99.4 & 95.4 & 102.8 & 97.5 & 99.2 & 103.6 & 100.0 \\
\hline \multirow[t]{4}{*}{2002} & Qtr 1 & 99.1 & 98.1 & 95.0 & 100.0 & 94.6 & 99.4 & 101.5 & 99.2 \\
\hline & Qtr 2 & 97.2 & 93.2 & 90.4 & 99.9 & 92.7 & 99.5 & 101.8 & 100.5 \\
\hline & Qtr 3 & 96.7 & 92.9 & 90.4 & 99.9 & 93.5 & 99.5 & 101.8 & 98.9 \\
\hline & Qtr 4 & 96.6 & 92.5 & 90.4 & 99.9 & 93.5 & 99.5 & 101.8 & 99.0 \\
\hline \multirow[t]{4}{*}{2003} & Qtr 1 & 96.5 & 92.2 & 90.4 & 100.2 & 93.5 & 99.5 & 101.8 & 98.9 \\
\hline & Qtr 2 & 96.4 & 92.3 & 90.4 & 100.1 & 93.6 & 99.5 & 101.8 & 98.4 \\
\hline & Qtr 3 & 96.7 & 93.0 & 92.8 & 100.2 & 93.6 & 99.5 & 101.8 & 98.1 \\
\hline & Qtr 4 & 96.6 & 92.8 & 92.8 & 99.9 & 93.6 & 99.5 & 101.7 & 98.3 \\
\hline \multirow[t]{4}{*}{2004} & Qtr 1 & 98.0 & 94.2 & 93.9 & 99.5 & 92.8 & 99.5 & 102.3 & 101.3 \\
\hline & Qtr 2 & 100.9 & 99.4 & 95.1 & 100.7 & 93.8 & 101.1 & 105.1 & 101.2 \\
\hline & Qtr 3 & 101.0 & 98.5 & 95.1 & 100.7 & 93.8 & 101.1 & 107.1 & 101.3 \\
\hline & Qtr 4 & 106.0 & 100.8 & 98.0 & 104.0 & 93.9 & 188.0 & 110.5 & 99.8 \\
\hline \multirow[t]{4}{*}{2005} & Qtr 1 & 106.8 & 101.4 & 106.8 & 104.0 & 93.9 & 184.0 & 112.1 & 100.1 \\
\hline & Qtr 2 & 108.2 & 101.5 & 106.8 & 104.0 & 93.9 & 197.9 & 115.9 & 100.1 \\
\hline & Qtr 3 & 109.6 & 101.7 & 106.8 & 104.0 & 93.9 & 211.8 & 119.7 & 100.1 \\
\hline & Qtr 4 & 111.0 & 101.9 & 106.8 & 104.0 & 93.9 & 225.7 & 123.6 & 100.1 \\
\hline \multirow[t]{2}{*}{2006} & Qtr 1 & 110.7 & 101.3 & 106.8 & 104.6 & 95.6 & 227.1 & 122.6 & 100.0 \\
\hline & & \multicolumn{8}{|c|}{ (Four-quarter percent change) } \\
\hline \multirow[t]{4}{*}{2003} & Qtr 1 & -2.6 & -6.1 & -4.8 & 0.1 & -1.2 & 0.2 & 0.3 & -0.2 \\
\hline & Qtr 2 & -0.9 & -1.0 & 0.0 & 0.3 & 0.9 & 0.0 & 0.0 & -2.0 \\
\hline & Qtr 3 & 0.0 & 0.2 & 2.6 & 0.3 & 0.2 & 0.0 & 0.0 & -0.8 \\
\hline & Qtr 4 & 0.0 & 0.4 & 2.6 & 0.0 & 0.2 & 0.0 & -0.1 & -0.7 \\
\hline \multirow[t]{4}{*}{2004} & Qtr 1 & 1.6 & 2.2 & 3.9 & -0.6 & -0.7 & 0.0 & 0.4 & 2.4 \\
\hline & Qtr 2 & 4.7 & 7.7 & 5.2 & 0.6 & 0.3 & 1.6 & 3.3 & 2.8 \\
\hline & Qtr 3 & 4.4 & 5.9 & 2.5 & 0.6 & 0.3 & 1.6 & 5.3 & 3.3 \\
\hline & Qtr 4 & 9.6 & 8.6 & 5.6 & 4.2 & 0.3 & 88.9 & 8.6 & 1.5 \\
\hline \multirow[t]{4}{*}{2005} & Qtr 1 & 8.9 & 7.6 & 13.7 & 4.5 & 1.1 & 84.9 & 9.6 & -1.2 \\
\hline & Qtr 2 & 7.2 & 2.1 & 12.3 & 3.3 & 0.0 & 95.8 & 10.3 & -1.1 \\
\hline & Qtr 3 & 8.5 & 3.3 & 12.3 & 3.3 & 0.0 & 109.5 & 11.8 & -1.2 \\
\hline & Qtr 4 & 4.8 & 1.1 & 9.0 & 0.0 & 0.0 & 20.1 & 11.8 & 0.3 \\
\hline 2006 & Qtr 1 & 3.7 & -0.1 & 0.0 & 0.6 & 1.8 & 23.4 & 9.4 & 0.0 \\
\hline
\end{tabular}

Source: Data provided by the Micronesian authorities. 
Table 9. Federated States of Micronesia: Yap Consumer Price Index, 2000-06

\begin{tabular}{|c|c|c|c|c|c|c|c|c|c|}
\hline & & Total & Food & $\begin{array}{c}\text { Tob, Alch, } \\
\text { Betelnut, } \\
\text { Sakau }\end{array}$ & $\begin{array}{l}\text { Clothing, } \\
\text { Footwear }\end{array}$ & Housing & $\begin{array}{c}\text { Fuel, Light \& } \\
\text { Water }\end{array}$ & Services & Miscellaneous \\
\hline & Weight & 14.9 & 4.8 & 1.9 & 0.3 & 0.5 & 0.8 & 3.0 & 3.5 \\
\hline & & \multicolumn{8}{|c|}{$(2000=100)$} \\
\hline \multirow[t]{4}{*}{2000} & Qtr 1 & 100.1 & 101.2 & 99.0 & 98.3 & 100.4 & 99.6 & 100.6 & 99.1 \\
\hline & Qtr 2 & 100.6 & 101.2 & 100.6 & 94.1 & 100.3 & 101.9 & 104.1 & 97.1 \\
\hline & Qtr 3 & 101.4 & 101.9 & 102.2 & 94.2 & 100.2 & 103.2 & 105.6 & 97.1 \\
\hline & Qtr 4 & 102.1 & 101.4 & 102.9 & 94.2 & 100.3 & 103.3 & 105.7 & 100.3 \\
\hline \multirow[t]{4}{*}{2001} & Qtr 1 & 102.5 & 100.7 & 104.5 & 94.4 & 99.2 & 105.5 & 110.1 & 98.0 \\
\hline & Qtr 2 & 103.4 & 101.9 & 108.4 & 93.3 & 100.5 & 105.5 & 110.4 & 97.5 \\
\hline & Qtr 3 & 103.6 & 101.5 & 109.4 & 92.5 & 97.1 & 105.2 & 112.1 & 97.6 \\
\hline & Qtr 4 & 103.0 & 101.9 & 105.6 & 91.8 & 96.5 & 102.4 & 112.8 & 96.9 \\
\hline \multirow[t]{4}{*}{2002} & Qtr 1 & 102.7 & 101.0 & 105.1 & 91.6 & 96.3 & 102.6 & 113.1 & 97.0 \\
\hline & Qtr 2 & 103.4 & 101.8 & 105.9 & 91.8 & 96.5 & 104.8 & 113.6 & 97.1 \\
\hline & Qtr 3 & 102.5 & 100.2 & 104.0 & 91.5 & 96.0 & 104.9 & 113.6 & 96.6 \\
\hline & Qtr 4 & 102.7 & 100.7 & 104.7 & 91.4 & 95.7 & 104.9 & 113.9 & 96.4 \\
\hline \multirow[t]{4}{*}{2003} & Qtr 1 & 102.1 & 100.2 & 100.9 & 91.1 & 96.2 & 104.9 & 114.1 & 96.2 \\
\hline & Qtr 2 & 101.5 & 99.0 & 102.3 & 90.6 & 95.9 & 96.1 & 114.9 & 96.3 \\
\hline & Qtr 3 & 102.0 & 100.1 & 102.3 & 91.1 & 96.2 & 96.0 & 114.2 & 97.2 \\
\hline & Qtr 4 & 101.9 & 99.9 & 99.5 & 91.0 & 95.1 & 96.2 & 115.4 & 97.5 \\
\hline \multirow[t]{4}{*}{2004} & Qtr 1 & 101.5 & 99.5 & 98.3 & 90.5 & 96.2 & 96.5 & 115.2 & 97.4 \\
\hline & Qtr 2 & 100.1 & 99.1 & 100.1 & 76.0 & 97.0 & 96.6 & 110.7 & 95.7 \\
\hline & Qtr 3 & 100.7 & 99.8 & 98.2 & 81.7 & 99.2 & 97.0 & 113.1 & 95.4 \\
\hline & Qtr 4 & 101.3 & 100.3 & 93.8 & 81.8 & 101.0 & 99.8 & 117.0 & 95.6 \\
\hline \multirow[t]{4}{*}{2005} & Qtr 1 & 104.5 & 100.5 & 106.2 & 81.7 & 104.5 & 127.6 & 116.8 & 95.3 \\
\hline & Qtr 2 & 105.3 & 101.3 & 107.2 & 81.8 & 103.8 & 130.0 & 120.2 & 93.7 \\
\hline & Qtr 3 & 106.9 & 102.9 & 109.5 & 89.5 & 105.2 & 131.3 & 121.6 & 94.5 \\
\hline & Qtr 4 & 107.0 & 101.9 & 110.6 & 89.5 & 105.3 & 132.1 & 123.1 & 94.5 \\
\hline \multirow[t]{2}{*}{2006} & Qtr 1 & 107.6 & 103.4 & 110.7 & 91.4 & 106.7 & 132.1 & 122.9 & 94.5 \\
\hline & & \multicolumn{8}{|c|}{ (Four-quarter percent change) } \\
\hline \multirow[t]{4}{*}{2003} & Qtr 1 & -0.7 & -0.8 & -4.0 & -0.6 & -0.2 & 2.2 & 0.9 & -0.8 \\
\hline & Qtr 2 & -1.8 & -2.8 & -3.4 & -1.3 & -0.6 & -8.3 & 1.1 & -0.9 \\
\hline & Qtr 3 & -0.5 & -0.1 & -1.6 & -0.4 & 0.2 & -8.5 & 0.5 & 0.6 \\
\hline & Qtr 4 & -0.9 & -0.8 & -5.0 & -0.5 & -0.6 & -8.3 & 1.3 & 1.1 \\
\hline \multirow[t]{4}{*}{2004} & Qtr 1 & -0.5 & -0.7 & -2.6 & -0.7 & 0.1 & -8.0 & 1.0 & 1.2 \\
\hline & Qtr 2 & -1.4 & 0.2 & -2.1 & -16.1 & 1.1 & 0.5 & -3.6 & -0.6 \\
\hline & Qtr 3 & -1.3 & -0.3 & -3.9 & -10.3 & 3.1 & 1.0 & -0.9 & -1.8 \\
\hline & Qtr 4 & -0.5 & 0.4 & -5.7 & -10.1 & 6.2 & 3.7 & 1.4 & -1.9 \\
\hline \multirow[t]{4}{*}{2005} & Qtr 1 & 2.9 & 1.1 & 8.0 & -9.7 & 8.6 & 32.2 & 1.4 & -2.1 \\
\hline & Qtr 2 & 5.2 & 2.2 & 7.1 & 7.6 & 7.0 & 34.6 & 8.6 & -2.1 \\
\hline & Qtr 3 & 6.1 & 3.1 & 11.4 & 9.5 & 6.1 & 35.4 & 7.5 & -1.0 \\
\hline & Qtr 4 & 5.6 & 1.6 & 17.9 & 9.4 & 4.2 & 32.4 & 5.2 & -1.1 \\
\hline 2006 & Qtr 1 & 2.9 & 2.8 & 4.3 & 11.9 & 2.1 & 3.6 & 5.2 & -0.9 \\
\hline
\end{tabular}

Source: Data provided by the Micronesian authorities. 
Table 10. Federated States of Micronesia: Consolidated General Government Finances FY2001-06 1/

\begin{tabular}{|c|c|c|c|c|c|c|}
\hline & FY2001 & FY2002 & $\begin{array}{r}\text { FY2003 } \\
\text { Est. }\end{array}$ & $\begin{array}{r}\text { FY2004 } \\
\text { Est. }\end{array}$ & $\begin{array}{r}\text { FY2005 } \\
\text { Est. }\end{array}$ & $\begin{array}{r}\text { FY2006 } \\
\text { Proj. }\end{array}$ \\
\hline & \multicolumn{6}{|c|}{ (In millions of U.S. dollars) } \\
\hline Total revenue and grants & 141.1 & 160.3 & 158.1 & 133.3 & 134.1 & 130.0 \\
\hline Total revenue & 45.4 & 47.0 & 44.1 & 53.9 & 49.6 & 48.3 \\
\hline Tax revenue & 26.5 & 26.3 & 23.9 & 27.2 & 29.1 & 29.8 \\
\hline Wages and salary tax & 6.0 & 7.5 & 6.4 & 8.0 & 6.5 & 6.7 \\
\hline Gross revenue tax & 6.9 & 6.2 & 5.2 & 6.0 & 6.8 & 6.9 \\
\hline Import tax:Fuel & 0.9 & 0.8 & 0.6 & 0.6 & 0.6 & 0.6 \\
\hline Import tax:All others & 7.0 & 5.9 & 5.4 & 6.1 & 8.2 & 8.4 \\
\hline All other tax (National) & 0.2 & 0.9 & 0.1 & 0.0 & 0.3 & 0.3 \\
\hline State tax revenue & 5.5 & 4.9 & 6.2 & 6.5 & 6.7 & 6.8 \\
\hline Nontax revenue & 19.0 & 20.7 & 20.1 & 26.7 & 20.5 & 18.6 \\
\hline Fishing access revenue & 11.3 & 10.6 & 11.8 & 12.1 & 13.1 & 12.5 \\
\hline Dividend and interest income & 2.1 & 2.3 & 0.9 & 2.5 & 1.5 & 0.1 \\
\hline Other nontax revenues & 5.5 & 7.9 & 7.4 & 12.1 & 6.0 & 6.0 \\
\hline Grants & 95.6 & 113.3 & 114.1 & 79.4 & 84.5 & 81.7 \\
\hline Grants from abroad & 95.6 & 113.3 & 114.1 & 79.4 & 84.5 & 81.7 \\
\hline Current grants & 70.5 & 81.5 & 86.7 & 78.7 & 84.5 & 76.8 \\
\hline Compact General & 37.4 & 47.7 & 43.9 & 0.0 & 0.0 & 0.0 \\
\hline Compact Special & 17.8 & 18.2 & 22.7 & 53.2 & 55.5 & 55.4 \\
\hline Other:Current & 15.2 & 15.5 & 20.1 & 25.5 & 29.1 & 21.3 \\
\hline Capital grants & 25.1 & 31.8 & 27.4 & 0.7 & 0.0 & 4.9 \\
\hline Compact CIP & 25.0 & 31.8 & 25.3 & 0.0 & 0.0 & 0.0 \\
\hline Other:Capital & 0.2 & 0.0 & 2.1 & 0.7 & 0.0 & 4.9 \\
\hline Total expenditure & 154.2 & 143.0 & 156.5 & 147.2 & 146.9 & 133.9 \\
\hline Current expenditure & 123.3 & 119.7 & 128.4 & 120.2 & 133.4 & 125.8 \\
\hline Expenditure on goods and services & 122.1 & 113.1 & 121.6 & 115.4 & 129.1 & 122.6 \\
\hline Wages and salaries & 54.3 & 58.1 & 60.2 & 57.1 & 59.1 & 57.5 \\
\hline Travel & 8.9 & 7.8 & 8.4 & 7.4 & 8.5 & 8.4 \\
\hline Other & 58.9 & 47.2 & 53.0 & 51.0 & 61.6 & 56.6 \\
\hline Interest payments & 0.6 & 0.0 & 0.0 & 0.0 & 0.0 & 0.1 \\
\hline Subsidies & 3.6 & 4.4 & 3.4 & 1.1 & 0.6 & 0.3 \\
\hline Transfers & -3.1 & 2.2 & 3.4 & 3.8 & 3.7 & 2.8 \\
\hline Capital expenditure & 30.9 & 23.3 & 28.0 & 27.0 & 13.5 & 8.2 \\
\hline Acquisition of fixed capital & 12.1 & 4.6 & 13.6 & 5.1 & 9.9 & 8.2 \\
\hline Multi-purpose development projects & 18.5 & 17.7 & 14.5 & 9.5 & 3.7 & 0.0 \\
\hline Capital Transfers & 0.3 & 1.0 & 0.0 & 12.4 & 0.0 & 0.0 \\
\hline Net lending (domestic) & 0.0 & 0.0 & 0.0 & 0.0 & 0.0 & 0.0 \\
\hline Overall balance & -13.1 & 17.3 & 1.7 & -13.9 & -12.8 & -3.9 \\
\hline Current balance & -7.4 & 8.8 & 2.3 & 12.4 & 0.7 & -0.7 \\
\hline Capital balance & -5.8 & 8.5 & -0.7 & -26.3 & -13.5 & -3.2 \\
\hline
\end{tabular}

Source: Data provided by the Micronesian authorities and Fund staff estimates.

1/ Fiscal year ending September 30. 
Table 11. Federated States of Micronesia: National Government Finances FY2001-06 1/

\begin{tabular}{|c|c|c|c|c|c|c|}
\hline & FY2001 & FY2002 & $\begin{array}{r}\text { FY2003 } \\
\text { Est. }\end{array}$ & $\begin{array}{r}\text { FY2004 } \\
\text { Est. }\end{array}$ & $\begin{array}{r}\text { FY2005 } \\
\text { Est. }\end{array}$ & $\begin{array}{r}\text { FY2006 } \\
\text { Proj. }\end{array}$ \\
\hline & \multicolumn{6}{|c|}{ (In millions of U.S. dollars) } \\
\hline Total revenue and grants & 37.8 & 42.8 & 46.1 & 48.6 & 47.5 & 45.6 \\
\hline Total revenue & 19.6 & 22.0 & 19.4 & 25.8 & 26.5 & 26.2 \\
\hline Tax revenue & 5.7 & 7.5 & 6.2 & 9.7 & 11.2 & 11.7 \\
\hline Wages and salary tax & 1.5 & 2.8 & 2.2 & 4.0 & 3.2 & 3.4 \\
\hline Gross revenue tax & 1.8 & 1.9 & 1.8 & 2.8 & 3.5 & 3.6 \\
\hline Import tax: fuel & 0.2 & 0.1 & 0.1 & 0.1 & 0.1 & 0.1 \\
\hline Import tax: all others & 2.1 & 1.8 & 1.9 & 2.9 & 4.1 & 4.3 \\
\hline All other tax (national) & 0.2 & 0.9 & 0.1 & 0.0 & 0.3 & 0.3 \\
\hline Nontax revenue & 13.9 & 14.5 & 13.2 & 16.1 & 15.2 & 14.5 \\
\hline Fishing access revenue & 11.3 & 10.6 & 11.8 & 12.1 & 13.1 & 12.5 \\
\hline Dividend and interest income & 0.7 & 0.3 & 0.1 & 1.9 & 0.1 & 0.0 \\
\hline Other nontax revenues & 1.8 & 3.6 & 1.2 & 2.1 & 2.0 & 2.0 \\
\hline Grants & 18.2 & 20.8 & 26.7 & 22.7 & 21.0 & 19.4 \\
\hline Grants from abroad & 18.2 & 20.8 & 26.7 & 22.7 & 21.0 & 19.4 \\
\hline Current grants & 15.9 & 17.8 & 21.7 & 22.0 & 21.0 & 14.5 \\
\hline Compact general & 5.5 & 7.0 & 7.0 & 0.0 & 0.0 & 0.0 \\
\hline Compact special & 4.1 & 4.8 & 4.8 & 9.4 & 6.2 & 5.5 \\
\hline Other:Current & 6.3 & 6.1 & 9.9 & 12.6 & 14.8 & 9.0 \\
\hline Capital grants & 2.3 & 3.0 & 5.0 & 0.7 & 0.0 & 4.9 \\
\hline Compact CIP & 2.3 & 3.0 & 3.0 & 0.0 & 0.0 & 0.0 \\
\hline Other: capital & 0.0 & 0.0 & 2.1 & 0.7 & 0.0 & 4.9 \\
\hline Total expenditure and net lending & 50.3 & 44.4 & 49.5 & 43.9 & 48.3 & 45.3 \\
\hline Total expenditure & 50.3 & 44.4 & 49.5 & 43.9 & 48.3 & 45.3 \\
\hline Current expenditure & 47.0 & 40.8 & 45.0 & 41.7 & 45.3 & 40.2 \\
\hline Expenditure on goods and services & 42.0 & 35.2 & 39.8 & 37.0 & 40.9 & 37.3 \\
\hline Wages and salaries & 11.6 & 12.7 & 14.1 & 12.8 & 11.6 & 10.5 \\
\hline Travel & 5.2 & 4.4 & 5.4 & 4.6 & 5.2 & 5.1 \\
\hline Other & 25.2 & 18.0 & 20.3 & 19.6 & 24.1 & 21.7 \\
\hline Interest payments & 0.0 & 0.0 & 0.0 & 0.0 & 0.0 & 0.1 \\
\hline Subsidies & 1.6 & 2.2 & 1.5 & 0.7 & 0.3 & 0.2 \\
\hline Transfers & 3.4 & 3.4 & 3.7 & 4.0 & 4.1 & 2.6 \\
\hline Including transfers to state governments & 6.4 & 2.3 & 0.9 & 0.9 & 1.1 & 0.0 \\
\hline Capital expenditure & 3.3 & 3.7 & 4.5 & 2.2 & 3.0 & 5.2 \\
\hline Acquisition of fixed capital & 1.6 & 1.4 & 1.9 & 1.2 & 2.6 & 5.2 \\
\hline Multi-purpose development projects & 1.7 & 1.3 & 2.6 & 1.0 & 0.3 & 0.0 \\
\hline Capital transfers & 0.0 & 1.0 & 0.0 & 0.0 & 0.0 & 0.0 \\
\hline Net lending (domestic) & 0.0 & 0.0 & 0.0 & 0.0 & 0.0 & 0.0 \\
\hline Overall balance & -12.6 & -1.6 & -3.4 & 4.7 & -0.8 & 0.3 \\
\hline Current balance & -11.6 & -0.9 & -4.0 & 6.2 & 2.2 & 0.5 \\
\hline Capital balance & -1.0 & -0.7 & 0.6 & -1.5 & -3.0 & -0.2 \\
\hline
\end{tabular}

Source: Data provided by the Micronesian authorities and Fund staff estimates.

1/ Fiscal year ending September 30. 
Table 12. Federated States of Micronesia: Pohnpei Government Finances FY2001-06 1/

\begin{tabular}{|c|c|c|c|c|c|c|}
\hline & FY2001 & FY2002 & $\begin{array}{r}\text { FY2003 } \\
\text { Est. }\end{array}$ & $\begin{array}{r}\text { FY2004 } \\
\text { Est. }\end{array}$ & $\begin{array}{r}\text { FY2005 } \\
\text { Est. }\end{array}$ & $\begin{array}{r}\text { FY2006 } \\
\text { Proj. }\end{array}$ \\
\hline & \multicolumn{6}{|c|}{ (In millions of U.S. dollars) } \\
\hline Total revenue and grants & 33.2 & 38.1 & 38.5 & 34.8 & 29.0 & 26.5 \\
\hline Total revenue & 9.9 & 10.8 & 11.2 & 14.7 & 9.4 & 8.4 \\
\hline Tax revenue & 8.8 & 9.8 & 8.0 & 7.5 & 7.3 & 7.4 \\
\hline Wages and salary tax & 2.4 & 2.7 & 2.1 & 1.8 & 1.5 & 1.6 \\
\hline Gross revenue tax & 1.8 & 2.2 & 1.8 & 1.4 & 1.4 & 1.4 \\
\hline Import tax: fuel & 0.3 & 0.3 & 0.2 & 0.2 & 0.1 & 0.1 \\
\hline Import tax: all others & 1.9 & 2.0 & 1.5 & 1.3 & 1.5 & 1.6 \\
\hline State tax revenue & 2.4 & 2.4 & 2.4 & 2.7 & 2.7 & 2.7 \\
\hline Nontax revenue & 1.1 & 1.1 & 3.2 & 7.2 & 2.2 & 1.0 \\
\hline Dividend and interest income & 0.1 & 0.3 & 0.3 & 0.4 & 1.2 & 0.0 \\
\hline Other nontax revenues & 1.0 & 0.7 & 2.9 & 6.8 & 1.0 & 1.0 \\
\hline Grants & 23.4 & 27.3 & 27.3 & 20.1 & 19.6 & 18.1 \\
\hline Grants from abroad & 22.1 & 26.5 & 27.1 & 19.9 & 19.5 & 18.1 \\
\hline Current grants & 15.8 & 18.4 & 19.0 & 19.9 & 19.5 & 18.1 \\
\hline Compact general & 8.8 & 11.2 & 11.2 & 0.0 & 0.0 & 0.0 \\
\hline Compact special & 3.8 & 3.7 & 3.9 & 15.4 & 16.0 & 14.0 \\
\hline Other:Current & 3.1 & 3.4 & 3.8 & 4.5 & 3.6 & 4.1 \\
\hline Capital grants & 6.4 & 8.1 & 8.1 & 0.0 & 0.0 & 0.0 \\
\hline Compact CIP & 6.4 & 8.1 & 8.1 & 0.0 & 0.0 & 0.0 \\
\hline Other: capital & 0.0 & 0.0 & 0.0 & 0.0 & 0.0 & 0.0 \\
\hline Grants from national government & 1.2 & 0.8 & 0.2 & 0.2 & 0.1 & 0.0 \\
\hline Current & 1.2 & 0.8 & 0.2 & 0.2 & 0.1 & 0.0 \\
\hline Capital & 0.0 & 0.0 & 0.0 & 0.0 & 0.0 & 0.0 \\
\hline Total expenditure and net lending & 30.4 & 32.2 & 36.0 & 40.3 & 30.0 & 27.4 \\
\hline Total expenditure & 30.4 & 32.2 & 36.0 & 40.3 & 30.0 & 27.4 \\
\hline Current expenditure & 23.9 & 24.4 & 30.8 & 27.2 & 27.4 & 27.4 \\
\hline Expenditure on goods and services & 23.7 & 24.1 & 30.7 & 27.1 & 27.0 & 27.4 \\
\hline Wages and salaries & 13.6 & 14.1 & 15.2 & 15.5 & 15.8 & 16.0 \\
\hline Travel & 0.7 & 0.8 & 0.7 & 0.7 & 0.7 & 0.7 \\
\hline Other & 9.3 & 9.2 & 14.8 & 10.9 & 10.5 & 10.6 \\
\hline Interest payments & 0.1 & 0.0 & 0.0 & 0.0 & 0.0 & 0.0 \\
\hline Subsidies & 0.1 & 0.3 & 0.1 & 0.1 & 0.2 & 0.0 \\
\hline Transfers & 0.0 & 0.0 & 0.0 & 0.0 & 0.1 & 0.0 \\
\hline Capital expenditure & 6.5 & 7.8 & 5.2 & 13.1 & 2.6 & 0.0 \\
\hline Acquisition of fixed capital & 1.6 & 1.0 & 0.7 & 0.9 & 0.8 & 0.0 \\
\hline Multi-purpose development projects & 4.9 & 6.8 & 4.4 & 4.8 & 1.8 & 0.0 \\
\hline Capital transfers & 0.0 & 0.0 & 0.0 & 7.5 & 0.0 & 0.0 \\
\hline Net lending (domestic) & 0.0 & 0.0 & 0.0 & 0.0 & 0.0 & 0.0 \\
\hline Overall balance & 2.8 & 5.9 & 2.5 & -5.5 & -0.9 & -1.0 \\
\hline Current balance & 3.0 & 5.6 & -0.4 & 7.6 & 1.7 & -1.0 \\
\hline Capital balance & -0.2 & 0.3 & 2.9 & -13.1 & -2.6 & 0.0 \\
\hline
\end{tabular}

Source: Data provided by the Micronesian authorities and Fund staff estimates.

$1 /$ Fiscal year ending September 30. 
Table 13. Federated States of Micronesia: Kosrae Government Finances FY2001-06 1/

\begin{tabular}{|c|c|c|c|c|c|c|}
\hline & FY2001 & FY2002 & $\begin{array}{r}\text { FY2003 } \\
\text { Est. }\end{array}$ & $\begin{array}{r}\text { FY2004 } \\
\text { Est. }\end{array}$ & $\begin{array}{r}\text { FY2005 } \\
\text { Est. }\end{array}$ & $\begin{array}{r}\text { FY2006 } \\
\text { Proj }\end{array}$ \\
\hline & \multicolumn{6}{|c|}{ (In millions of U.S. dollars) } \\
\hline Total revenue and grants & 13.8 & 14.8 & 15.5 & 10.4 & 12.3 & 10.6 \\
\hline Total revenue & 1.4 & 2.1 & 2.5 & 2.8 & 2.6 & 2.6 \\
\hline Tax revenue & 1.9 & 1.5 & 1.4 & 1.3 & 1.2 & 1.2 \\
\hline Wages and salary tax & 0.5 & 0.4 & 0.4 & 0.4 & 0.3 & 0.3 \\
\hline Gross revenue tax & 0.5 & 0.5 & 0.3 & 0.3 & 0.2 & 0.2 \\
\hline Import tax: fuel & 0.1 & 0.1 & 0.1 & 0.1 & 0.0 & 0.0 \\
\hline Import tax: all others & 0.5 & 0.4 & 0.4 & 0.3 & 0.3 & 0.3 \\
\hline State tax revenue & 0.2 & 0.2 & 0.2 & 0.3 & 0.3 & 0.3 \\
\hline Nontax revenue & -0.4 & 0.6 & 1.1 & 1.5 & 1.4 & 1.4 \\
\hline Dividend and interest income & -0.8 & 0.2 & 0.4 & 0.2 & 0.1 & 0.1 \\
\hline Other nontax revenues & 0.3 & 0.4 & 0.7 & 1.3 & 1.3 & 1.3 \\
\hline Grants & 12.4 & 12.8 & 13.0 & 7.6 & 9.7 & 8.0 \\
\hline Grants from abroad & 10.6 & 12.5 & 13.0 & 7.5 & 9.5 & 8.0 \\
\hline Current grants & 7.7 & 8.7 & 9.2 & 7.5 & 9.5 & 8.0 \\
\hline Compact general & 3.4 & 4.4 & 4.4 & 0.0 & 0.0 & 0.0 \\
\hline Compact special & 2.1 & 2.0 & 2.3 & 5.8 & 7.5 & 6.0 \\
\hline Other:Current & 2.2 & 2.3 & 2.6 & 1.7 & 2.0 & 2.0 \\
\hline Capital grants & 3.0 & 3.8 & 3.8 & 0.0 & 0.0 & 0.0 \\
\hline Compact CIP & 3.0 & 3.8 & 3.8 & 0.0 & 0.0 & 0.0 \\
\hline Other: capital & 0.0 & 0.0 & 0.0 & 0.0 & 0.0 & 0.0 \\
\hline Grants from national government & 1.7 & 0.2 & 0.0 & 0.1 & 0.2 & 0.0 \\
\hline Current & 0.1 & 0.1 & 0.0 & 0.0 & 0.2 & 0.0 \\
\hline Capital & 1.6 & 0.1 & 0.0 & 0.1 & 0.0 & 0.0 \\
\hline Total expenditure and net lending & 14.6 & 14.5 & 14.9 & 11.6 & 12.2 & 10.8 \\
\hline Total expenditure & 14.6 & 14.5 & 14.9 & 11.6 & 12.2 & 10.8 \\
\hline Current expenditure & 9.5 & 10.9 & 12.6 & 10.6 & 10.7 & 10.8 \\
\hline Expenditure on goods and services & 9.0 & 10.1 & 12.1 & 10.6 & 10.7 & 10.8 \\
\hline Wages and salaries & 5.0 & 5.7 & 6.2 & 6.2 & 6.3 & 6.4 \\
\hline Travel & 0.7 & 0.8 & 0.7 & 0.7 & 0.6 & 0.6 \\
\hline Other & 3.3 & 3.6 & 5.3 & 3.6 & 3.7 & 3.8 \\
\hline Interest payments & 0.0 & 0.0 & 0.0 & 0.0 & 0.0 & 0.0 \\
\hline Subsidies & 0.5 & 0.5 & 0.5 & 0.0 & 0.0 & 0.0 \\
\hline Transfers & 0.0 & 0.4 & 0.0 & 0.0 & 0.0 & 0.0 \\
\hline Capital expenditure & 5.1 & 3.5 & 2.3 & 1.0 & 1.6 & 0.0 \\
\hline Acquisition of fixed capital & 0.3 & 0.3 & 0.3 & 0.3 & 0.9 & 0.0 \\
\hline Multi-purpose development projects & 4.6 & 3.2 & 2.0 & 0.8 & 0.6 & 0.0 \\
\hline Capital transfers & 0.3 & 0.0 & 0.0 & 0.0 & 0.0 & 0.0 \\
\hline Net lending (domestic) & 0.0 & 0.0 & 0.0 & 0.0 & 0.0 & 0.0 \\
\hline Overall balance & -0.8 & 0.3 & 0.7 & -1.3 & 0.1 & -0.2 \\
\hline Current balance & -0.3 & 0.0 & -0.9 & -0.3 & 1.6 & -0.2 \\
\hline Capital balance & -0.6 & 0.4 & 1.5 & -1.0 & -1.6 & 0.0 \\
\hline
\end{tabular}

Source: Data provided by the Micronesian authorities and Fund staff estimates.

1/ Fiscal year ending September 30. 
Table 14. Federated States of Micronesia: Yap Government Finances

FY2001-06 1/

\begin{tabular}{|c|c|c|c|c|c|c|}
\hline & FY2001 & FY2002 & $\begin{array}{r}\text { FY2003 } \\
\text { Est. }\end{array}$ & $\begin{array}{r}\text { FY2004 } \\
\text { Est. }\end{array}$ & $\begin{array}{r}\text { FY2005 } \\
\text { Est. }\end{array}$ & $\begin{array}{r}\text { FY2006 } \\
\text { Proj. }\end{array}$ \\
\hline & \multicolumn{6}{|c|}{ (In millions of U.S. dollars) } \\
\hline Total revenue and grants & 24.0 & 24.6 & 22.8 & 15.5 & 20.2 & 16.5 \\
\hline Total revenue & 6.3 & 6.4 & 4.4 & 5.1 & 5.3 & 5.3 \\
\hline Tax revenue & 3.8 & 3.2 & 2.7 & 3.9 & 4.0 & 4.0 \\
\hline Wages and salary tax & 0.3 & 0.7 & 0.5 & 1.0 & 0.4 & 0.4 \\
\hline Gross revenue tax & 1.5 & 0.7 & 0.4 & 0.7 & 0.7 & 0.7 \\
\hline Import tax: fuel & 0.1 & 0.1 & 0.0 & 0.0 & 0.1 & 0.1 \\
\hline Import tax: all others & 1.1 & 0.9 & 0.5 & 0.7 & 1.1 & 1.1 \\
\hline State tax revenue & 0.9 & 0.8 & 1.3 & 1.4 & 1.6 & 1.7 \\
\hline Nontax revenue & 2.5 & 3.3 & 1.7 & 1.2 & 1.3 & 1.3 \\
\hline Dividend and interest income & 1.8 & 0.9 & 0.0 & 0.0 & 0.0 & 0.0 \\
\hline Other nontax revenues & 0.7 & 2.4 & 1.7 & 1.2 & 1.3 & 1.3 \\
\hline Grants & 17.7 & 18.1 & 18.4 & 10.4 & 14.9 & 11.1 \\
\hline Grants from abroad & 15.2 & 17.4 & 17.6 & 10.2 & 14.4 & 11.1 \\
\hline Current grants & 11.3 & 12.7 & 12.9 & 10.2 & 14.4 & 11.1 \\
\hline Compact general & 6.0 & 7.6 & 7.6 & 0.0 & 0.0 & 0.0 \\
\hline Compact special & 2.8 & 2.8 & 2.7 & 6.7 & 7.4 & 8.8 \\
\hline Other:Current & 2.5 & 2.3 & 2.6 & 3.5 & 7.0 & 2.4 \\
\hline Capital grants & 3.9 & 4.7 & 4.7 & 0.0 & 0.0 & 0.0 \\
\hline Compact CIP & 3.7 & 4.7 & 4.7 & 0.0 & 0.0 & 0.0 \\
\hline Other: capital & 0.2 & 0.0 & 0.0 & 0.0 & 0.0 & 0.0 \\
\hline Grants from national government & 2.5 & 0.7 & 0.8 & 0.2 & 0.5 & 0.0 \\
\hline Current & 2.4 & 0.7 & 0.0 & 0.0 & 0.2 & 0.0 \\
\hline Capital & 0.1 & 0.0 & 0.8 & 0.2 & 0.2 & 0.0 \\
\hline Total expenditure and net lending & 20.1 & 16.9 & 17.0 & 22.7 & 25.3 & 17.5 \\
\hline Total expenditure & 20.1 & 16.9 & 17.0 & 22.7 & 25.3 & 17.5 \\
\hline Current expenditure & 14.2 & 15.0 & 15.3 & 15.5 & 20.6 & 14.5 \\
\hline Expenditure on goods and services & 13.4 & 14.0 & 14.7 & 15.0 & 20.3 & 14.2 \\
\hline Wages and salaries & 5.6 & 6.0 & 6.3 & 6.2 & 7.2 & 6.1 \\
\hline Travel & 1.1 & 1.4 & 0.8 & 0.9 & 1.0 & 1.0 \\
\hline Other & 6.7 & 6.6 & 7.6 & 7.9 & 12.1 & 7.1 \\
\hline Interest payments & 0.6 & 0.0 & 0.0 & 0.0 & 0.0 & 0.0 \\
\hline Subsidies & 0.2 & 0.3 & 0.1 & 0.2 & 0.1 & 0.1 \\
\hline Transfers & 0.0 & 0.7 & 0.6 & 0.3 & 0.2 & 0.2 \\
\hline Capital expenditure & 5.9 & 1.8 & 1.7 & 7.3 & 4.7 & 3.0 \\
\hline Acquisition of fixed capital & 5.4 & 1.5 & 0.9 & 1.7 & 4.2 & 3.0 \\
\hline Multi-purpose development projects & 0.5 & 0.3 & 0.8 & 0.7 & 0.5 & 0.0 \\
\hline Capital transfers & 0.0 & 0.0 & 0.0 & 4.9 & 0.0 & 0.0 \\
\hline Net lending (domestic) & 0.0 & 0.0 & 0.0 & 0.0 & 0.0 & 0.0 \\
\hline Overall balance & 3.9 & 7.7 & 5.7 & -7.2 & -5.1 & -1.0 \\
\hline Current balance & 5.8 & 4.8 & 2.0 & -0.2 & -0.7 & 2.0 \\
\hline Capital balance & -1.9 & 2.9 & 3.8 & -7.0 & -4.5 & -3.0 \\
\hline
\end{tabular}

Source: Data provided by the Micronesian authorities and Fund staff estimates.

1/ Fiscal year ending September 30. 
Table 15. Federated States of Micronesia: Chuuk Government Finances FY2001-06 1/

\begin{tabular}{|c|c|c|c|c|c|c|}
\hline & FY2001 & FY2002 & $\begin{array}{r}\text { FY2003 } \\
\text { Est. }\end{array}$ & $\begin{array}{r}\text { FY2004 } \\
\text { Est. }\end{array}$ & $\begin{array}{r}\text { FY2005 } \\
\text { Est. }\end{array}$ & $\begin{array}{r}\text { FY2006 } \\
\text { Proj. }\end{array}$ \\
\hline & \multicolumn{6}{|c|}{ (In millions of U.S. dollars) } \\
\hline Total revenue and grants & 38.7 & 42.2 & 36.2 & 24.6 & 25.9 & 30.8 \\
\hline Total revenue & 8.3 & 5.6 & 6.6 & 5.5 & 5.8 & 5.9 \\
\hline Tax revenue & 6.3 & 4.4 & 5.6 & 4.8 & 5.3 & 5.4 \\
\hline Wages and salary tax & 1.4 & 0.9 & 1.1 & 0.9 & 1.0 & 1.0 \\
\hline Gross revenue tax & 1.3 & 0.9 & 0.9 & 0.8 & 0.9 & 0.9 \\
\hline Import tax: fuel & 0.3 & 0.2 & 0.2 & 0.2 & 0.2 & 0.2 \\
\hline Import tax: all others & 1.4 & 0.9 & 1.1 & 0.9 & 1.1 & 1.1 \\
\hline State tax revenue & 2.0 & 1.5 & 2.3 & 2.1 & 2.2 & 2.2 \\
\hline Nontax revenue & 2.0 & 1.3 & 1.0 & 0.7 & 0.5 & 0.5 \\
\hline Dividend and interest income & 0.3 & 0.5 & 0.0 & 0.1 & 0.0 & 0.0 \\
\hline Other nontax revenues & 1.7 & 0.7 & 1.0 & 0.6 & 0.4 & 0.4 \\
\hline Grants & 30.5 & 36.6 & 29.6 & 19.1 & 20.1 & 25.0 \\
\hline Grants from abroad & 29.5 & 36.1 & 29.6 & 19.1 & 20.1 & 25.0 \\
\hline Current grants & 19.9 & 23.9 & 23.9 & 19.1 & 20.1 & 25.0 \\
\hline Compact general & 13.8 & 17.5 & 13.7 & 0.0 & 0.0 & 0.0 \\
\hline Compact special & 5.1 & 5.0 & 9.0 & 15.8 & 18.3 & 21.1 \\
\hline Other:Current & 1.1 & 1.4 & 1.2 & 3.3 & 1.7 & 3.9 \\
\hline Capital grants & 9.6 & 12.2 & 5.7 & 0.0 & 0.0 & 0.0 \\
\hline Compact CIP & 9.6 & 12.2 & 5.7 & 0.0 & 0.0 & 0.0 \\
\hline Other: capital & 0.0 & 0.0 & 0.0 & 0.0 & 0.0 & 0.0 \\
\hline Grants from national government & 1.0 & 0.5 & 0.0 & 0.0 & 0.0 & 0.0 \\
\hline Current & 1.0 & 0.5 & 0.0 & 0.0 & 0.0 & 0.0 \\
\hline Capital & 0.0 & 0.0 & 0.0 & 0.0 & 0.0 & 0.0 \\
\hline Total expenditure and net lending & 45.2 & 37.3 & 40.0 & 29.2 & 31.9 & 32.8 \\
\hline Total expenditure & 45.2 & 37.3 & 40.0 & 29.2 & 31.9 & 32.8 \\
\hline Current expenditure & 35.1 & 30.8 & 25.6 & 25.8 & 30.3 & 32.8 \\
\hline Expenditure on goods and services & 34.1 & 29.7 & 24.3 & 25.8 & 30.3 & 32.8 \\
\hline Wages and salaries & 18.4 & 19.5 & 18.5 & 16.4 & 18.1 & 18.4 \\
\hline Travel & 1.3 & 0.5 & 0.8 & 0.6 & 1.0 & 1.0 \\
\hline Other & 14.4 & 9.7 & 5.0 & 8.9 & 11.1 & 13.4 \\
\hline Interest payments & -0.1 & 0.0 & 0.0 & 0.0 & 0.0 & 0.0 \\
\hline Subsidies & 1.2 & 1.0 & 1.2 & 0.0 & 0.0 & 0.0 \\
\hline Transfers & 0.0 & 0.0 & 0.1 & 0.0 & 0.0 & 0.0 \\
\hline Capital expenditure & 10.0 & 6.5 & 14.4 & 3.3 & 1.7 & 0.0 \\
\hline Acquisition of fixed capital & 3.3 & 0.5 & 9.7 & 1.0 & 1.2 & 0.0 \\
\hline Multi-purpose development projects & 6.8 & 6.0 & 4.7 & 2.3 & 0.4 & 0.0 \\
\hline Capital transfers & 0.0 & 0.0 & 0.0 & 0.0 & 0.0 & 0.0 \\
\hline Net lending (domestic) & 0.0 & 0.0 & 0.0 & 0.0 & 0.0 & 0.0 \\
\hline Overall balance & -6.4 & 4.9 & -3.8 & -4.5 & -6.1 & -2.0 \\
\hline Current balance & -6.0 & -0.8 & 4.9 & -1.2 & -4.4 & -2.0 \\
\hline Capital balance & -0.4 & 5.7 & -8.7 & -3.3 & -1.7 & 0.0 \\
\hline
\end{tabular}

Source: Data provided by the Micronesian authorities and Fund staff estimates.

1/ Fiscal year ending September 30. 
Table 16. Federated States of Micronesia: Banking Survey, 2001-06 1/

(In millions of U.S. dollars; end of period)

\begin{tabular}{|c|c|c|c|c|c|c|}
\hline & 2001 & 2002 & 2003 & 2004 & 2005 & 2006 \\
\hline Assets & 138.6 & 128.3 & 137.1 & 131.2 & 128.4 & 136.1 \\
\hline Liquid Assets & 82.2 & 83.5 & 107.7 & 104.4 & 97.2 & 103.4 \\
\hline Cash and due from local banks & 4.4 & 5.2 & 3.1 & 4.0 & 3.6 & 4.1 \\
\hline Foreign assets - due from banks abroad & 77.8 & 78.3 & 104.6 & 100.5 & 93.6 & 99.4 \\
\hline Loans & 52.0 & 39.1 & 24.0 & 21.3 & 25.7 & 26.9 \\
\hline Commercial loans & 18.3 & 21.0 & 10.1 & 8.8 & 10.7 & 11.1 \\
\hline Consumer loans & 33.8 & 18.1 & 13.9 & 12.5 & 14.9 & 15.8 \\
\hline Other assets & 4.4 & 5.7 & 5.4 & 5.5 & 5.6 & 5.8 \\
\hline Liabilities & 138.6 & 128.3 & 137.1 & 131.2 & 128.4 & 136.1 \\
\hline Deposits & 121.7 & 112.0 & 119.8 & 115.4 & 111.4 & 118.6 \\
\hline Demand & 24.2 & 25.5 & 28.1 & 28.0 & 28.3 & 29.2 \\
\hline Savings & 42.8 & 44.7 & 60.2 & 56.6 & 50.3 & 58.2 \\
\hline Time & 54.5 & 41.7 & 31.4 & 30.7 & 32.8 & 31.2 \\
\hline Other & 0.2 & 0.1 & 0.1 & 0.1 & 0.1 & 0.0 \\
\hline Liabilities and capital & 17.0 & 16.3 & 17.3 & 15.8 & 17.0 & 17.4 \\
\hline & \multicolumn{6}{|c|}{ (In percent) } \\
\hline \multicolumn{7}{|l|}{ Memorandum items: } \\
\hline Loan/deposit ratio & 42.8 & 34.9 & 20.0 & 18.5 & 23.0 & 22.7 \\
\hline Commercial loan share of total & 35.1 & 53.8 & 42.1 & 41.2 & 41.8 & 41.3 \\
\hline Consumer loan share of total & 64.9 & 46.2 & 57.9 & 58.8 & 58.2 & 58.7 \\
\hline Deposits annual rate of change & 0.7 & -7.9 & 6.9 & -3.7 & -3.4 & 1.3 \\
\hline Loans annual rate of change & -0.7 & -24.9 & -38.7 & -11.0 & 20.4 & 17.6 \\
\hline Commercial loans annual rate of change & -14.1 & 15.0 & -52.0 & -13.0 & 22.1 & 27.9 \\
\hline Consumer loans annual rate of change & 8.5 & -46.5 & -23.3 & -9.6 & 19.2 & 11.4 \\
\hline
\end{tabular}

Source: Micronesian Banking Board.

1 / On a fiscal year basis. 
Table 17. Federated States of Micronesia: Interest Rates of Deposit Money Banks, 2001-06 1/

(In percent per annum; end of period)

\begin{tabular}{lrrrrrr}
\hline & 2001 & 2002 & 2003 & 2004 & 2005 & 2006 \\
\hline & & & & & & \\
& & & & & & \\
Deposit rates 2/ & 1.7 & 1.3 & 0.9 & 0.9 & 1.1 & 1.9 \\
$\quad$ Savings deposits & 1.5 & 1.3 & 0.9 & 1.3 & 2.4 & 2.5 \\
CDs & 3.1 & 1.3 & 1.0 & 1.0 & 1.5 & 2.1 \\
$\quad$ Other deposits & & & & & & \\
Loan rates 2/ & 15.3 & 15.0 & 15.0 & 16.5 & 16.5 & 16.5 \\
$\quad$ Consumer loans & 5.9 & 4.8 & 7.0 & 7.5 & 9.5 & 8.9 \\
Commercial loans & & & & & & \\
\end{tabular}

Source: Data provided by the Micronesian authorities.

1/ On calendar year basis. Data for 2006 are for end-October.

2/ Average of rates offered and charged by deposit money banks. 
Table 18. Federated States of Micronesia: Balance of Payments, FY2001-06

(In millions of U.S. dollars)

\begin{tabular}{|c|c|c|c|c|c|c|}
\hline & FY2001 & FY2002 & FY2003 & FY2004 & FY2005 & FY2006 \\
\hline Trade balance & -94.8 & -84.6 & -91.8 & -119.3 & -121.2 & -111.7 \\
\hline Exports, f.o.b. & 26.5 & 26.9 & 28.3 & 17.5 & 20.1 & 21.4 \\
\hline Imports, f.o.b. 1/ & -121.3 & -111.5 & -120.1 & -136.8 & -141.3 & -133.1 \\
\hline Petroleum products & -17.4 & -14.9 & -14.3 & -16.7 & -22.3 & -23.5 \\
\hline Services account & -34.9 & -36.0 & -36.1 & -37.4 & -40.0 & -39.8 \\
\hline Receipts & 16.8 & 18.9 & 18.6 & 18.2 & 18.6 & 19.2 \\
\hline Travel & 14.7 & 16.8 & 16.7 & 16.5 & 17.1 & 17.5 \\
\hline Communications (net) & 1.8 & 2.1 & 1.9 & 1.5 & 1.3 & 1.5 \\
\hline Other & 0.3 & 0.1 & 0.1 & 0.3 & 0.1 & 0.1 \\
\hline Payments & -51.7 & -55.0 & -54.8 & -55.6 & -58.6 & -59.0 \\
\hline Freight and insurance & -21.4 & -19.7 & -21.2 & -24.1 & -26.6 & -27.0 \\
\hline Transportation & -10.8 & -12.2 & -10.8 & -11.4 & -12.0 & -12.0 \\
\hline Travel & -5.4 & -5.3 & -5.6 & -5.3 & -5.6 & -5.6 \\
\hline Other & -14.2 & -17.8 & -17.2 & -14.8 & -14.4 & -14.4 \\
\hline Income, net & 11.9 & 10.8 & 12.0 & 16.4 & 18.6 & 17.7 \\
\hline Receipts & 18.1 & 16.4 & 18.7 & 22.7 & 24.6 & 23.7 \\
\hline Fishing rights fees & 11.3 & 10.6 & 11.8 & 12.1 & 14.4 & 12.5 \\
\hline Interest dividend income & 6.8 & 5.8 & 6.8 & 10.6 & 10.2 & 11.2 \\
\hline Payments & -6.2 & -5.6 & -6.6 & -6.2 & -5.9 & -6.0 \\
\hline Foreign workers earnings & -2.8 & -2.6 & -3.4 & -3.1 & -2.8 & -2.8 \\
\hline Interest payments & -2.0 & -1.7 & -1.8 & -1.8 & -1.6 & -1.6 \\
\hline Dividends & -1.4 & -1.4 & -1.4 & -1.4 & -1.5 & -1.5 \\
\hline Unrequited transfers & 91.9 & 104.2 & 118.1 & 99.6 & 106.2 & 102.7 \\
\hline Private & 2.3 & 2.3 & 2.3 & 2.5 & 3.3 & 5.3 \\
\hline Inflows & 4.7 & 4.8 & 4.9 & 5.0 & 6.0 & 8.0 \\
\hline Outflows & -2.5 & -2.5 & -2.6 & -2.5 & -2.7 & -2.7 \\
\hline Official & 89.6 & 101.9 & 115.8 & 97.1 & 102.9 & 97.4 \\
\hline Compact funds & 55.3 & 65.9 & 66.6 & 51.7 & 53.2 & 55.4 \\
\hline Other & 34.4 & 36.0 & 49.1 & 45.4 & 49.7 & 42.0 \\
\hline Current account balance & -25.9 & -5.7 & 2.2 & -40.7 & -36.4 & -31.1 \\
\hline Capital and financial account & 21.1 & 37.7 & 16.1 & -14.8 & 15.6 & 17.0 \\
\hline Capital transfers & 32.1 & 39.1 & 39.8 & -22.5 & 8.1 & 17.5 \\
\hline Capital transfers, official & 25.0 & 31.8 & 32.2 & -28.6 & 1.1 & 4.9 \\
\hline Capital transfers, in-kind & 7.1 & 7.3 & 7.6 & 6.1 & 7.1 & 12.6 \\
\hline Financial account & -10.9 & -1.4 & -23.6 & 7.7 & 7.4 & -0.5 \\
\hline Short term, net & -2.1 & -0.8 & -25.0 & 7.5 & 6.9 & -0.5 \\
\hline Medium term, net & -8.8 & -0.6 & 1.3 & 0.2 & 0.5 & 0.0 \\
\hline Inflows & 0.0 & 0.0 & 2.0 & 1.1 & 1.4 & 2.1 \\
\hline Medium-term notes (MTN) & 0.0 & 0.0 & 0.0 & 0.0 & 0.0 & 0.0 \\
\hline Other borrowing & 0.0 & 0.0 & 2.0 & 1.1 & 1.4 & 2.1 \\
\hline Outflows & -8.8 & -0.6 & -0.6 & -0.8 & -0.9 & -0.9 \\
\hline MTN amortization & -8.2 & 0.0 & 0.0 & 0.0 & 0.0 & 0.0 \\
\hline Other amortization & -0.6 & -0.6 & -0.6 & -0.8 & -0.9 & -0.9 \\
\hline Overall balance & -4.8 & 32.1 & 18.3 & -55.5 & -20.8 & -14.1 \\
\hline
\end{tabular}

Source: Data provided by the Micronesian authorities. 
Table 19. Federated States of Micronesia: External Debt and Debt Service Obligations, FY2000-05

(In millions of U.S. dollars)

\begin{tabular}{|c|c|c|c|c|c|c|}
\hline & FY2000 & FY2001 & FY2002 & FY2003 & FY2004 & FY2005 \\
\hline \multicolumn{7}{|l|}{ Total external debt (end of period) } \\
\hline New & 2.2 & 0.0 & 0.0 & 2.0 & 1.1 & 1.4 \\
\hline Outstanding & 85.8 & 66.8 & 58.5 & 59.9 & 60.3 & 60.8 \\
\hline Amortization & 19.1 & 8.8 & 0.6 & 0.6 & 0.8 & 0.9 \\
\hline Interest & 3.8 & 2.1 & 1.8 & 1.8 & 1.8 & 1.6 \\
\hline Principal balance & 66.8 & 58.5 & 57.9 & 59.2 & 59.4 & 59.9 \\
\hline External debt in percent of GDP & 30.7 & 26.5 & 25.9 & 25.7 & 26.5 & 25.3 \\
\hline Debt service in percent of exports $1 /$ & 56.9 & 25.1 & 5.2 & 5.2 & 7.2 & 6.5 \\
\hline \multicolumn{7}{|l|}{ FSM Telecomm borrowing } \\
\hline New & 0.0 & 0.0 & 0.0 & 0.0 & 0.0 & n.a. \\
\hline Outstanding & 28.5 & 28.0 & 27.9 & 27.3 & 26.7 & 26.0 \\
\hline Amortization & 0.6 & 0.6 & 0.6 & 0.6 & 0.7 & 0.7 \\
\hline Interest & 1.5 & 1.5 & 1.5 & 1.4 & 1.4 & 1.3 \\
\hline Principal balance & 28.0 & 27.9 & 27.3 & 26.7 & 26.0 & 25.2 \\
\hline \multicolumn{7}{|l|}{ ADB fisheries project (MLFC) } \\
\hline New & 0.0 & 0.0 & 0.0 & 0.0 & 0.0 & 0.0 \\
\hline Outstanding & 3.8 & 3.8 & 3.8 & 3.8 & 3.8 & 3.7 \\
\hline Amortization & 0.0 & 0.0 & 0.0 & 0.0 & 0.1 & 0.1 \\
\hline Interest & 0.0 & 0.0 & 0.0 & 0.0 & 0.0 & 0.0 \\
\hline Principal balance & 3.8 & 3.8 & 3.8 & 3.8 & 3.7 & 3.5 \\
\hline \multicolumn{7}{|l|}{ ADB water/sanitation project } \\
\hline New & 2.2 & 0.0 & 0.0 & 0.0 & 0.0 & n.a \\
\hline Outstanding & 8.8 & 8.8 & 8.8 & 8.8 & 8.8 & 8.8 \\
\hline Amortization & 0.0 & 0.0 & 0.0 & 0.0 & 0.0 & 0.0 \\
\hline Interest & 0.1 & 0.1 & 0.1 & 0.1 & 0.1 & 0.1 \\
\hline Principal balance & 8.8 & 8.8 & 8.8 & 8.8 & 8.8 & 8.8 \\
\hline \multicolumn{7}{|l|}{ ADB PSRP program loan* } \\
\hline New & 0.0 & 0.0 & 0.0 & 0.0 & 0.0 & n.a \\
\hline Outstanding & 18.0 & 18.0 & 18.0 & 18.0 & 18.0 & 18.0 \\
\hline Amortization & 0.0 & 0.0 & 0.0 & 0.0 & 0.0 & 0.0 \\
\hline Interest & 0.2 & 0.2 & 0.2 & 0.2 & 0.2 & 0.2 \\
\hline Principal balance & 18.0 & 18.0 & 18.0 & 18.0 & 18.0 & 18.0 \\
\hline \multicolumn{7}{|l|}{ ADB Basic Social Services Project loan* } \\
\hline New & 0.0 & 0.0 & 0.0 & 0.0 & 0.1 & 0.4 \\
\hline Outstanding & 0.0 & 0.0 & 0.0 & 0.0 & 0.1 & 0.4 \\
\hline Amortization & 0.0 & 0.0 & 0.0 & 0.0 & 0.0 & 0.0 \\
\hline Interest & 0.0 & 0.0 & 0.0 & 0.0 & 0.0 & 0.0 \\
\hline Principal balance & 0.0 & 0.0 & 0.0 & 0.0 & 0.1 & 0.4 \\
\hline \multicolumn{7}{|c|}{ ADB Private Sector Development Program Ioan } \\
\hline New & 0.0 & 0.0 & 0.0 & 1.9 & 0.7 & 0.0 \\
\hline Outstanding & 0.0 & 0.0 & 0.0 & 1.9 & 2.5 & 2.5 \\
\hline Amortization & 0.0 & 0.0 & 0.0 & 0.0 & 0.0 & 0.0 \\
\hline Interest & 0.0 & 0.0 & 0.0 & 0.0 & 0.0 & 0.0 \\
\hline Principal balance & 0.0 & 0.0 & 0.0 & 1.9 & 2.5 & 2.5 \\
\hline \multicolumn{7}{|c|}{ ADB Private Sector Development Program loan II } \\
\hline New & 0.0 & 0.0 & 0.0 & 0.1 & 0.4 & 1.0 \\
\hline Outstanding & 0.0 & 0.0 & 0.0 & 0.1 & 0.5 & 1.5 \\
\hline Amortization & 0.0 & 0.0 & 0.0 & 0.0 & 0.0 & 0.0 \\
\hline Interest & 0.0 & 0.0 & 0.0 & 0.0 & 0.0 & 0.0 \\
\hline Principal balance & 0.0 & 0.0 & 0.0 & 0.1 & 0.5 & 1.5 \\
\hline
\end{tabular}

Source: Department of Finance and Administration and EMPAT estimates.

$1 /$ Export of goods and services. 